\title{
PRODUTOS NATURAIS: ATUALIDADE, DESAFIOS E PERSPECTIVAS
}

\author{
Angelo C. Pinto \\ Instituto de Química, Universidade Federal do Rio de Janeiro, CT, Bloco A, Cidade Universitária Ilha do Fundão, 21949-900 \\ Rio de Janeiro - RJ \\ Dulce Helena Siqueira Silva e Vanderlan da Silva Bolzani* \\ Instituto de Química, Universidade Estadual Paulista, CP 355, 14801-970 Araraquara - SP \\ Norberto Peporine Lopes \\ Faculdade de Ciências Farmacêuticas de Ribeirão Preto, Universidade de São Paulo, Av. do Café, s/n, 14040-903 Ribeirão Preto - SP \\ Rosângela de Almeida Epifanio \\ Instituto de Química, Universidade Federal Fluminense, Outeiro de São João Batista, s/n, 24210-150 Niterói - RJ
}

\begin{abstract}
CURRENT STATUS, CHALLENGES AND TRENDS ON NATURAL PRODUCTS IN BRAZIL. This article offers an overview on the historical facts and the recent state of art of Chemistry of Natural Products which, in the course of 25 years of SBQ, have led to the present development of this area in Brazil. In addition, this article deals with the last trends on Natural Products in Brazil and also in developed countries.
\end{abstract}

Keywords: Chemistry of Natural Products; 25 years of SBQ; historical facts and trends.

\section{INTRODUÇÃO}

O Brasil, com a grandeza de seu litoral, de sua flora e, sendo o detentor da maior floresta equatorial e tropical úmida do planeta, não pode abdicar de sua vocação para os produtos naturais. A Química de Produtos Naturais (QPN) é, dentro da Química brasileira, a área mais antiga e a que, talvez ainda hoje, congregue o maior número de pesquisadores.

Para facilitar a compreensão do texto e melhor situá-lo no contexto da QPN brasileira, julgou-se apropriado descrever alguns marcos históricos na evolução dessa área, sem a pretensão de hierarquizar estes marcos, mesmo porque a simples escolha e definição de limites depende do autor da escolha e por isso é sempre um ato pessoal e muitas vezes até arbitrário.

Os primeiros médicos portugueses que vieram para o Brasil, diante da escassez, na colônia, de remédios empregados na Europa, muito cedo foram obrigados a perceber a importância dos remédios indígenas. Os viajantes sempre se abasteciam destes remédios antes de excursionarem por regiões pouco conhecidas. Os primeiros cronistas da história brasileira, para citar apenas dois, foram: Pero de Magalhães Gândavo que escreveu "História da Província de Santa Cruz (a que vulgarmente chamamos Brasil)" em 1576, e Gabriel Soares de Souza, o autor de "Tratado Descritivo do Brasil", de 1587. Este último denominava os produtos medicinais utilizados pelos índios de "as árvores e ervas da virtude"1.

Além dos remédios naturais usados na terapêutica médica, não se pode deixar de mencionar o corante extraído da árvore do paubrasil, o principal produto de exportação da colônia durante mais de dois séculos, e um dos motivos para a colonização do Brasil pelos portugueses ${ }^{2}$.

Quando Portugal começou a perder suas fontes de especiarias, na Índia e na Ásia, que foram passando para as mãos de ingleses e holandeses, iniciou-se no Brasil a corrida às especiarias do sertão canela, baunilha, cravo, anil, raízes aromáticas, urucum, puxurí, salsa, sementes oleaginosas, madeiras etc... Em 1793, só de anil, foram exportadas 1400 arrobas para Portugal ${ }^{3}$.

\footnotetext{
*e-mail: bolzaniv@iq.unesp.br
}

A vinda da Corte Real para o Brasil, em 1808, e o decreto de D. João VI que abriu os portos brasileiros às nações amigas pode ser considerado como um dos primeiros marcos históricos oficiais na ciência brasileira, porque foi a partir deste decreto que começaram a chegar ao País as primeiras expedições científicas, cujo principal objetivo era dar conhecimento aos europeus da exuberância de nossa fauna e de nossa flora. A maioria dos naturalistas destas expedições vieram com a incumbência de coletar espécimes de animais e de plantas para os museus europeus. Não se pode, entretanto, deixar de mencionar que a Europa já tinha conhecimento, há muito tempo, de plantas medicinais brasileiras, através da obra "Historia Naturalis Brasiliae". Três homens foram responsáveis pelo conteúdo do livro: Georg Marcgrave, originário da Alemanha, mas tendo estudado em Leiden; Johannes de Laet, que editou a contribuição de Marcgrave e acrescentou comentários próprios, e o médico de Maurício de Nassau, Willem Piso. A contribuição de Piso consiste de quatro extensas discussões. A primeira sobre o ar, a água e a topografia do Brasil. A segunda, sobre doenças endêmicas locais. A terceira, sobre venenos e seus antídotos. E a quarta sobre plantas medicinais. Este livro representa a primeira história natural completa da América do $\mathrm{Sul}^{4}$.

Na comitiva que acompanhou a Princesa Leopoldina da Áustria, noiva de D. Pedro, veio o médico português Bernardino António Gomes, que no Laboratório Chimico da Casa da Moeda, em Lisboa, isolou a cinchonina das cascas da quina, antes de Pelletier e Caventou terem isolado a quinina das cascas da mesma planta. Formado em Medicina pela Universidade de Coimbra, em 1793, Bernardino António Gomes (1768-1823) prestou serviço, vários anos no Brasil, na Armada Portuguesa. No Brasil fez valiosas observações botânico-médicas sobre plantas locais que lhe conferiram grande notoriedade. A cinchonina foi o primeiro alcalóide natural sob a forma de base pura, na história da Química ${ }^{5}$.

Na mesma expedição científica vieram o médico e botânico Carl Friederich von Martius e o zoólogo Johann Baptist Spix, dois dos iniciadores do estudo sistemático da flora e da fauna brasileiras. Martius teve implicação direta com o início da fitoquímica brasileira. Esta afirmação é feita porque foi por sugestão de von Martius que o jovem farmacêutico alemão, Theodoro Peckolt, em 1847, veio para o Brasil para estudar a flora. Este farmacêutico pode ser considerado, 
pelo seu trabalho fantástico, o pai da fitoquímica brasileira, além de ser o patriarca de uma família de cientistas notáveis que se entregaram de corpo e alma ao estudo químico de plantas brasileiras. Inicialmente instalado na cidade de Cantagalo no Estado do Rio de Janeiro, a mesma cidade onde nasceu Rodolpho Albino Dias da Silva (1889-1931), o autor único da primeira farmacopéia brasileira, Peckolt mudou-se mais tarde para o Rio de Janeiro onde fundou a Farmácia Peckolt, na rua da Quitanda, 157 (posteriormente, 197). Em 1874, Peckolt foi contratado para reorganizar o laboratório químico do Museu Nacional, no período da direção de Lasdilau Neto. O ano de 1874 pode ser considerado o ano do início dos estudos de QPN numa instituição pública brasileira. Entre os muitos trabalhos de Peckolt pode-se destacar o isolamento da substância de Plumeria lancifolia, que ele denominou de agoniadina. Este foi o primeiro iridóide a ser isolado da natureza em forma pura. Só 88 anos depois do seu isolamento teve sua estrutura química determinada ${ }^{6}$. Hoje este iridóide, muito comum na família Apocynaceae, é conhecido como plumerídeo ${ }^{7}$. Na época de Peckolt a atividade em QPN estava voltada para a comercialização de remédios e se desenvolvia nos laboratórios das antigas boticas. Foi numa farmácia localizada no Rio de Janeiro que o farmacêutico Ezequiel Correia dos Santos isolou, em 1838, o alcalóide pereirina das cascas do pau-pereira. A pereirina é um dos primeiros alcalóides, senão o primeiro, a ser isolado puro no Brasil $^{8}$.

Uma das instituições pioneiras de grande importância para a QPN foi a Faculdade de Medicina do Rio de Janeiro. Nessa escola, dentre os que se dedicaram ao estudo químico de plantas, destaca-se o nome de Domingos José Freire Júnior (1842-1899), que foi catedrático da cadeira de Química Orgânica e Biológica (1874-1895). Domingos Freire, além de suas obras didáticas, deixou uma série de publicações científicas, algumas dessas na área de fitoquímica. Descreveu, por exemplo, a grandiflorina isolada da fruta do lobo (Solanum grandiflora $)^{9}$. Esse alcalóide é hoje conhecido pelo nome de solasonina ${ }^{10}$.

Outro pesquisador solitário que tem seu nome ligado à QPN é o farmacêutico Pedro Batista de Andrade (1848-1937), um dos fundadores da Faculdade de Farmácia da Universidade de São Paulo. Este pesquisador realizou, entre muitos outros, estudos sobre a composição química do café ${ }^{11}$.

No século XX, a década de 20 pode ser considerada a da "criação" e das mudanças. O ano de 1920 viu a criação oficial de oito cursos de Química Industrial, anexos a instituições técnicas ou de ensino já existentes ${ }^{12}$. Enquanto as artes explodem com a Semana de Arte Moderna e a política vê nascer o Partido Comunista Brasileiro, as ciências aprofundam suas raízes em solo firme. A Academia Brasileira de Ciências havia sido criada em 1916, e é na década de 20 que começam a ser fundadas as Sociedades Científicas, como por exemplo, a Sociedade Brasileira de Química em $1922^{13}$.

No período pós-primeira guerra mundial destacam-se, no norte do país, o nome de Paul Le Cointe, e no sudeste, o médico baiano Mario Saraiva (1885-1950). O francês Paul Le Cointe esteve ligado à Escola de Química Industrial do Pará, anexa ao Museu Comercial de Belém, do qual foi diretor ${ }^{13}$. Já Mario Saraiva foi idealizador e diretor durante anos do Instituto de Química Agrícola (IQA), no Rio de Janeiro. O IQA recebeu este nome em 1934, após ter sido criado, em 1918, com o nome de Instituto de Química. Este é, sem dúvida, o berço da QPN brasileira ${ }^{14}$. Daí, após sua extinção pelo decreto número 1477 de 26 de outubro de 1962, foi que se deu a grande diáspora que resultou na disseminação dos grupos que se dedicam hoje no país à QPN. O IQA, graças às pesquisas desenvolvidas pelo seu corpo de pesquisadores constituído, entre outros, por Otto Richard Gottlieb, Walter Baptist Mors, Benjamin Gilbert, Mauro Taveira Magalhães e Roderick Arthur Barnes, adquiriu grande prestígio nacional e internacional. A partir de dois químicos notáveis: Otto
Gottlieb e Walter Mors, que estavam no IQA na época de sua extinção, se consolidou a moderna fitoquímica brasileira. O primeiro, após longa peregrinação por quase todo território nacional estruturando grupos de QPN, se fixou no Instituto de Química da USP, a convite da direção da FAPESP ${ }^{14}$. O segundo foi o responsável pela criação do Centro de Pesquisas de Produtos Naturais (CPPN, atual NPPN), anexo à Faculdade de Farmácia da UFRJ, a convite do Prof. Paulo da Silva Lacaz.

Apesar da criação, em 1934, da Faculdade de Filosofia, Ciências e Letras da Universidade de São Paulo ser o marco principal da ciência brasileira, até a ida do Prof. Otto Gottlieb para o Instituto de Química da USP, foram muito poucos os trabalhos de pesquisas de QPN que lá se desenvolveram. Estudos, por exemplo, sobre o ácido anacárdico e seus derivados encontrados no óleo da castanha de caju, o cafestol do café, e a reína de Cassia alata foram feitos pelo Prof. Henrich Hauptmann (1905-1960) ${ }^{15}$.

Os pesquisadores formados sob orientação dos professores Otto R. Gottlieb, Massayoshi Yoshida e Nídia F. Roque no Instituto de Química da USP, a partir de 1970, e pelos professores Walter Mors, Benjamin Gilbert, Maria Auxiliadora C. Kaplan, Mauro T. Magalhães e Roderick A. Barnes, no Rio de Janeiro, são responsáveis pela implantação da maioria dos grupos de pesquisa em Produtos Naturais em todo o Brasil. Cabe destacar a professora Alaíde B. de Oliveira, orientada pelo professor Otto, que foi a grande responsável pelo crescimento da fitoquímica em Minas Gerais. Os 316 pesquisadores cadastrados atualmente no CNPq desenvolvem trabalhos em 11 linhas de pesquisa: Fitoquímica, Metodologia Analítica, Atividade Biológica, Ecologia Química, Síntese, Biossíntese, Biotransformação, Biotecnologia, Quimiossistemática, Produtos Naturais Marinhos e Química de Microrganismos/Insetos, assim divididas para possibilitar a análise dos dados referentes à diversificação de pesquisas dos grupos ou pesquisadores cadastrados nos arquivos do $\mathrm{CNPq}$ e da Divisão de PN-SBQ ${ }^{16}$.

A avaliação de áreas do conhecimento, em especial a de Produtos Naturais, tem sido realizada quase que continuamente nos últimos 25 anos, tornando-se um tema recorrente na ciência brasileira. Ao longo dos 25 anos de existência da Sociedade Brasileira de Química (SBQ), a QPN teve um crescimento marcante. Em 1994, com a criação das divisões científicas, a Divisão de Produtos Naturais se fortaleceu ainda mais devido ao trabalho conjunto das diretorias eleitas (ver Apêndice) e de seus membros (sócios vinculados à Divisão) que vêm sistematicamente realizando intensas discussões sobre o estado da arte em Produtos Naturais.

A evolução científica da QPN no Brasil teve seu marco histórico na fitoquímica clássica (isolamento e determinação estrutural), implantada e estruturada pelos pesquisadores de excelência já mencionados, de onde surgiram os grupos consolidados e atuantes na área por todo o país. Este panorama histórico pode ser acompanhado do desenvolvimento da pesquisa em QPN feita atualmente em nosso país. É importante salientar que vários desses grupos de pesquisa vêm alterando o enfoque da fitoquímica tradicional privilegiando trabalhos que envolvem atividade biológica, ecologia química e biossíntese de micromoléculas de plantas, microorganismos, organismos marinhos, entre outros, assim como novas metodologias analíticas de trabalho com produtos naturais, como uma maneira de atuar na fronteira do conhecimento, a exemplo do que ocorre nos países industrializados.

A Tabela 1 mostra a distribuição desses pesquisadores e seus grupos nas diversas áreas temáticas. A diferença entre as proporções observadas para cada linha de pesquisa segundo o CNPq e a DPN da SBQ é devida à consideração, pelo $\mathrm{CNPq}$, de todas as linhas desenvolvidas por cada grupo de pesquisa, enquanto os dados da DPN se referem à linha de pesquisa principal de cada grupo. 
A predominância de grupos engajados em trabalhos sobre atividade biológica deveria refletir a grande preocupação com a busca de aplicação para as moléculas isoladas de fontes naturais através do seu uso como modelos químicos para a indústria farmacêutica. Nos resumos dos Simpósios de Plantas Medicinais do Brasil, realizados a cada 2 anos, verifica-se a predominância de trabalhos sobre atividade biológica. No entanto, uma porcentagem significativa destes relata estudos de toxicologia e farmacologia de plantas medicinais (fitoterápicos) com resultados preliminares, pois são realizados com extratos vegetais brutos ou frações. Trabalhos envolvendo atividade farmacológica e toxicológica de princípios ativos puros são ainda pouco representativos.

Grande parte dos projetos de pesquisa submetidos ao CNPq ainda trata de fitoquímica tradicional. Essa constatação fica evidente quando se avalia o resultado das pesquisas desses grupos apresentados nas Reuniões Anuais da SBQ (Tabela 2) e nos resultados publicados nas revistas especializadas.

A análise dos resumos apresentados nas Reuniões Anuais da SBQ nos últimos 5 anos (1997 a 2001) (Tabela 2) revela o predomínio de trabalhos em fitoquímica, envolvendo principalmente isolamento e determinação estrutural (51\%) e desenvolvimento e aplicação de metodologias analíticas (16\%), enquanto trabalhos sobre atividade biológica representam cerca de $19 \%$. Esses números expressam a dificuldade que persiste em se realizar trabalhos multidisciplinares envolvendo fitoquímica e atividade biológica, apesar dos pesquisadores se proporem a realizar esse tipo de estudo.

De 1997 a 2001, o número de trabalhos com esse caráter multidisciplinar permaneceu praticamente inalterado. Todavia, a partir de 1999 observa-se um aumento significativo de trabalhos focalizando atividade biológica, o que pode estar sinalizando uma nova tendência, que enfatiza a realização de trabalhos em colaboração. A consolidação dessa tendência é clara, quando se verifica o aumento de cerca de $10 \%$ nos trabalhos enfocando atividade biológica, passando de cerca de 16\% em 1996 para 26\% em 2001. Aliada a essa perspectiva, tem-se o fato do enfoque biológico poder se traduzir numa possível aplicação, o que pode facilitar a obtenção de financiamentos à pesquisa de outras fontes extra governamentais. Neste início de século, constata-se que alguns grupos de pesquisa já contam com apoio financeiro parcial do setor produtivo nacional.

O Brasil já possui massa crítica para atuar nessa nova realidade de pesquisa. Isso pode ser verificado pela porcentagem de artigos publicados por autores brasileiros em revistas nacionais com corpo editorial como J. Braz. Chem. Soc. e Quim. Nova (Tabela 3) e internacionais como Phytochemistry, Planta Med., J. Nat. Prod., Phytother. Res. e J. Ethnopharmacol. (Tabela 4). Se considerarmos Phytochemistry e J. Nat. Prod. como as revistas mais representativas para divulgação de trabalhos realizados nos cinco continentes, com grande participação dos países europeus, Estados Unidos, China e

Tabela 1. Dados sobre pesquisadores e suas áreas temáticas na pesquisa brasileira em Química de Produtos Naturais

\begin{tabular}{|c|c|c|c|c|}
\hline & \multicolumn{2}{|c|}{ Pesquisadores cadastrados no $\mathrm{CNPq}$} & \multicolumn{2}{|c|}{ Pesquisadores cadastrados na DPN-SBQ } \\
\hline & & $\%$ & & $\%$ \\
\hline Fitoquímica & 39 & 17 & 40 & 31 \\
\hline Metodologia Analítica & 9 & 4 & 7 & 5 \\
\hline Atividade Biológica & 84 & 36 & 37 & 28 \\
\hline Ecologia Química & 16 & 7 & 12 & 9 \\
\hline Síntese & 24 & 10 & 19 & 15 \\
\hline Biossíntese & 2 & 1 & 3 & 2 \\
\hline Biotransformação & 6 & 3 & - & - \\
\hline Biotecnologia (cultura de tecidos) & 8 & 3 & 4 & 3 \\
\hline Quimiossistemática & 24 & 10 & 5 & 4 \\
\hline Produtos Naturais Marinhos & 16 & 7 & 4 & 3 \\
\hline Química de Microrganismos & 6 & 3 & - & - \\
\hline Total & 234 & 100 & 131 & 100 \\
\hline
\end{tabular}

Tabela 2. Distribuição anual dos resumos apresentados pela Divisão de Produtos Naturais nas Reuniões da SBQ, conforme classificação de áreas temáticas

\begin{tabular}{|c|c|c|c|c|c|c|c|c|c|c|c|c|}
\hline \multirow{3}{*}{$\begin{array}{l}\text { Classificação /Ano } \\
\text { Fitoquímica }\end{array}$} & \multicolumn{2}{|c|}{1997} & \multicolumn{2}{|c|}{1998} & \multicolumn{2}{|c|}{1999} & \multicolumn{2}{|c|}{2000} & \multicolumn{2}{|c|}{2001} & \multirow[t]{2}{*}{ Total } & \multirow{2}{*}{$\begin{array}{c}\text { Média } \\
\%\end{array}$} \\
\hline & & $\%$ & \multicolumn{2}{|c|}{$\%$} & \multicolumn{2}{|r|}{$\%$} & \multicolumn{2}{|r|}{$\%$} & \multicolumn{2}{|r|}{$\%$} & & \\
\hline & 80 & $(61)$ & 90 & (49) & 108 & $(52)$ & 79 & (47) & 98 & (53) & 455 & 51 \\
\hline Metodologia Analítica & 19 & (15) & 42 & (23) & 36 & (17) & 28 & (17) & 17 & (9) & 142 & 16 \\
\hline Atividade Biológica & 21 & (16) & 27 & (15) & 39 & (19) & 38 & (22) & 49 & (26) & 174 & 19 \\
\hline Ecologia Química & 4 & (3) & 7 & (4) & 10 & $(5)$ & 6 & (4) & 8 & (4) & 35 & 4 \\
\hline Síntese & 2 & (2) & 2 & (1) & 3 & (1) & 1 & $(<1)$ & 1 & $(<1)$ & 9 & 1 \\
\hline Biossíntese e Biotransformação & 2 & (2) & 5 & (3) & 1 & (1) & 2 & (1) & 5 & (3) & 15 & 2 \\
\hline Biotecnologia & 1 & $(<1)$ & 2 & (1) & 1 & $(<1)$ & 1 & $(<1)$ & 2 & (1) & 7 & 1 \\
\hline Quimiossistemática & 2 & $(2)$ & 5 & (3) & 3 & (1) & 1 & $(<1)$ & 2 & (1) & 13 & 2 \\
\hline Produtos Naturais Marinhos & 4 & (3) & 3 & (2) & 4 & (2) & 3 & (2) & 0 & (0) & 14 & 2 \\
\hline Produtos Naturais de & 0 & (0) & 1 & $(<1)$ & 1 & $(<1)$ & 10 & (6) & 3 & (2) & 15 & 2 \\
\hline \multicolumn{13}{|l|}{ Microrganismos e Insetos } \\
\hline Total & 135 & & 183 & & 207 & & 169 & & 185 & & & \\
\hline
\end{tabular}


Tabela 3. Número de artigos sobre Produtos Naturais publicados nas revistas Journal of the Brazilian Chemical Society e Química Nova

\begin{tabular}{lccccccccccc}
\hline & \multicolumn{2}{c}{1997} & \multicolumn{2}{c}{1998} & & \multicolumn{2}{c}{1999} & & 2000 & 2001 \\
\hline & Total & PN & Total & PN & Total & PN & Total & PN & Total & PN \\
J. Braz. Chem. Soc. & 103 & $12(12 \%)$ & 92 & $20(22 \%)$ & 86 & $23(27 \%)$ & 100 & $29(29 \%)$ & 104 & $22(21 \%)$ \\
Quim. Nova & 103 & $14(14 \%)$ & 144 & $10(7 \%)$ & 147 & $14(10 \%)$ & 141 & $10(7 \%)$ & 120 & $11(9 \%)$ &
\end{tabular}

Tabela 4. Número de artigos de pesquisadores brasileiros publicados em periódicos internacionais nos últimos 4 anos

\begin{tabular}{|c|c|c|c|c|c|c|c|c|c|c|}
\hline & \multicolumn{2}{|c|}{1997} & \multicolumn{2}{|c|}{1998} & \multicolumn{2}{|c|}{1999} & \multicolumn{2}{|c|}{2000} & \multicolumn{2}{|r|}{2001} \\
\hline Biochem. Syst. Ecol. & $\begin{array}{c}\text { Total } \\
96\end{array}$ & $\begin{array}{r}\text { Brasil } \\
3(3 \%)\end{array}$ & $\begin{array}{c}\text { Total } \\
98\end{array}$ & $\begin{array}{l}\text { Brasil } \\
7(7 \%)\end{array}$ & $\begin{array}{c}\text { Total } \\
96\end{array}$ & $\begin{array}{r}\text { Brasil } \\
9(9 \%)\end{array}$ & $\begin{array}{l}\text { Total } \\
117\end{array}$ & $\begin{array}{c}\text { Brasil } \\
8(7 \%)\end{array}$ & $\begin{array}{l}\text { Total } \\
118\end{array}$ & $\begin{array}{r}\text { Brasil } \\
11(9 \%)\end{array}$ \\
\hline J. Braz. Chem. Soc.* & 12 & $12(100 \%)$ & 20 & $17(85 \%)$ & 23 & $23(100 \%)$ & 29 & $28(97 \%)$ & 30 & $30(100 \%)$ \\
\hline J. Ethnopharmacol. & 107 & $5(5 \%)$ & 137 & $12(9 \%)$ & 215 & $21(10 \%)$ & 288 & $25(9 \%)$ & 196 & $9(5 \%)$ \\
\hline J. Nat. Prod. & 339 & $4(1 \%)$ & 388 & $11(3 \%)$ & 452 & $12(3 \%)$ & 441 & $5(1 \%)$ & 404 & $9(2 \%)$ \\
\hline Phytochemistry & 850 & $42(5 \%)$ & 1118 & $67(6 \%)$ & 710 & $37(5 \%)$ & 564 & $56(10 \%)$ & 477 & $45(9 \%)$ \\
\hline Phytochem. Anal. & 52 & $7(14 \%)$ & 47 & $2(4 \%)$ & 54 & $4(7 \%)$ & 59 & $7(12 \%)$ & 66 & $7(11 \%)$ \\
\hline Phytother. Res. & 156 & $12(8 \%)$ & 195 & $13(7 \%)$ & 160 & $16(10 \%)$ & 146 & $12(8 \%)$ & 135 & $11(8 \%)$ \\
\hline Planta Med. & 188 & $10(5 \%)$ & 240 & $11(5 \%)$ & 241 & $10(4 \%)$ & 211 & $10(5 \%)$ & 231 & $6(3 \%)$ \\
\hline Quim. Nova* & 14 & $13(93 \%)$ & 10 & $10(100 \%)$ & 14 & $14(100 \%)$ & 10 & $10(100 \%)$ & 17 & $16(94 \%)$ \\
\hline
\end{tabular}

* Número de artigos sobre Produtos Naturais

Japão, conclui-se que a publicação de artigos de autores brasileiros em torno de 7 e $2 \%$, respectivamente, tem potencial para crescimento relevante, se considerarmos a vantagem do Brasil, sobre os países citados, em termos de biodiversidade.

Outro fator que está contribuindo para uma tomada de consciência pelo pesquisador brasileiro é o valor potencial da biodiversidade brasileira. Esta, encarada como fonte de produtos de alto valor agregado, requer políticas que garantam a sua exploração de forma racional. No estágio atual, são os países desenvolvidos, com uma biodiversidade pouco significativa, os produtores de substâncias úteis para a indústria farmacêutica, agroquímica etc, a partir de fontes naturais.

Apesar da necessidade de atuação nas áreas de fronteira do conhecimento, o Brasil possui uma característica territorial muito diferente dos países industrializados, marcada principalmente pela sua imensa biodiversidade, sendo, portanto, ainda um celeiro para a busca de substâncias novas, de interesse biológico ou não. Só um trabalho científico integrado de todos os grupos existentes no país poderá, num tempo limite, propiciar o conhecimento real da diversidade química dos ambientes tropicais e auxiliar nos estudos futuros sobre o perfil metabólico (metaboloma) e associações com perfil macromolecular (proteoma) das espécies de interesse de nossa biota.

Os pesquisadores desta área têm à mão a matéria prima mais abundante e diversificada do planeta. Estima-se que $20 \%$ desse patrimônio genético esteja concentrado em território nacional, onde o índice de endemismo é altíssimo. São 55 mil espécies vegetais (22\% do total registrado no planeta), 524 mamíferos (cerca de 131 endêmicos), 517 anfíbios (294 endêmicos), 1.622 aves (191 endêmicas), 468 répteis (172 endêmicos), 3 mil espécies de peixes de água doce e cerca de 15 milhões de insetos (muitos sem qualquer descrição taxonômica) ${ }^{17}$. Em levantamento recente, Myers et al. ${ }^{18}$ identificaram áreas do globo terrestre caracterizadas por excepcional concentração de espécies endêmicas e elevada degradação de habitat. Estas áreas denominadas de "hotspots", estão sendo exploradas de forma irracional pelo homem e necessitam de ações urgentes a fim de se evitar a extinção em massa das espécies nelas existentes em um futuro próximo. Dos 25 "hotspots" identificados no mundo, o Cerrado e a Mata Atlântica foram reconhecidos como áreas de maior risco de extinção, o que reforça a importância de uma massa crítica consolidada de pesquisadores que estudem estes ecossistemas, visando não somente sua preservação e o conhecimento do seu perfil químico, mas também a descoberta de novas substâncias úteis ao homem.

\section{PRODUTOS NATURAIS: ATUALIDADE E DESAFIO}

\section{Considerações gerais acerca da história da química de Produtos Naturais}

As primeiras descrições sobre plantas medicinais feitas pelo homem remontam às sagradas escrituras e ao papiro de Ebers. Este papiro foi descoberto e publicado por Georg Ebers, sendo traduzido pela primeira vez, em 1890, por H. Joachin. Foi encontrado nas proximidades da casa mortuária de Ramsés II, porém pertence à época da XVIII dinastia. Enumera mais ou menos 100 doenças e descreve um grande número de drogas de natureza animal e vegetal ${ }^{19}$.

Durante o período anterior à era cristã que ficou conhecido como civilização grega, vários filósofos podem ser destacados por suas obras sobre história natural. Dentre esses, sobressaem-se Hipócrates, considerado o pai da medicina moderna, que se caracterizou por tomar a natureza como guia na escolha dos remédios (Natura medicatrix) e Teofrasto (372 aC), discípulo de Aristóteles, que escreveu vários livros sobre a história das plantas. É seu o registro da utilização da espécie botânica Papaver somniferum, planta cujo princípio ativo é a morfina (1) ${ }^{11}$ (Documentos sumerianos de $5000 \mathrm{aC}$ referem-se à papoula ( $P$. somniferum) e tábulas assírias descrevem suas propriedades).

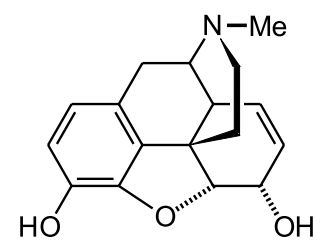

1 Morfina 
Evidências arqueológicas mostram que o uso de drogas era amplo em culturas antigas. Nozes de bétele, uma planta aromática que contém substâncias psicoativas, eram mascadas há 13 mil anos no Timor; e artefatos descobertos no Equador estendem o uso das folhas de coca a 5000 anos atrás.

No século I da era cristã destaca-se o eminente médico grego Dioscóride, autor de notável obra sobre medicina e farmácia intitulada "De Materia Medica" que serviu como guia de ensino nestas áreas até a época do Renascimento. No mesmo século, o naturalista latino Plínio, cognominado "O Velho", escreveu extensa obra sobre história natural. No século seguinte sobressai Galeno, farmacêutico e médico grego, autor de vários livros sobre medicina e farmácia. Suas formulações medicamentosas originaram a farmácia galênica.

Na Idade Média, no período entre 450-1000, conhecido como a "Idade Tenebrosa" devido ao obscurantismo religioso da ciência nesta época, a preocupação teológica invadiu os espíritos e somente a partir de século VII a ciência readquiriu importância entre os árabes.

A civilização árabe trouxe importantes contribuições à medicina natural. A ela deve-se o emprego dos purgativos vegetais e o conhecimento do sabor doce da urina dos diabéticos. No século $\mathrm{X}$, impõem-se o nome do médico islâmico Avicena (Abu Ali al Hussin ibn Abdallah ibn Sina), estudioso botânico, criador de um tratado sobre medicamentos cardíacos. Sua obra mais importante, "Canon", foi durante muito tempo o texto médico mais popular da Europa ${ }^{20}$.

O pensamento científico dos séculos XII e XIII sofreu forte controle da igreja. Esta época caracterizou-se por movimentos religiosos que ficaram conhecidos como Cruzadas. No âmbito da química ocidental, talvez o acontecimento mais importante deste período esteja relacionado com a utilização do alambique para destilação de álcool. Por volta de 1280, o florentino Thaddeo Alderotti (12231303) destilou vinho para propósitos medicamentosos. Cabe mencionar que evidências arqueológicas demonstram que o alambique era conhecido antes da era cristã ${ }^{21}$.

Todo o empirismo mágico-feiticeiro da arte de curar ao longo da história da humanidade, das teriagas às mandrágoras, encontra em Paracelso (1493-1541) sua figura mais polêmica. É sua a criação da teoria da "assinatura dos corpos" segundo a qual a "atividade farmacológica" de uma planta estaria relacionada com o seu aspecto morfológico. Assim, por exemplo, a serpentária, erva da família das aráceas cuja haste malhada lembra o corpo de uma serpente, serviria para a cura de picadas de cobra ${ }^{22}$.

As grandes navegações trouxeram a descoberta de novos continentes, legando ao mundo moderno um grande arsenal terapêutico de origem vegetal até hoje indispensável à medicina.

As culturas americanas, especialmente a Inca, Asteca, Maya, Olmeca e Tolteca consignaram à civilização moderna a quina, a ipecacuanha, a coca e muitas outras drogas de valor terapêutico ${ }^{23}$.

$\mathrm{O}$ isolamento das primeiras substâncias puras do reino vegetal começa a acontecer no século XVIII. Este século, juntamente com o XIX, caracteriza-se pelos trabalhos de extração, principalmente de ácidos orgânicos e de alcalóides. É desta época o isolamento de morfina (1) (1806), quinina (2) e estriquinina (3) $(1820)^{16}$.

Após a metade do século XVIII, Lavoisier (1743-1794) destruiu a teoria do flogístico criando as bases da química moderna ao estabelecer a natureza da combustão, permitindo desse modo a determinação da composição centesimal das substâncias orgânicas.

No século XIX, Wöhler (1828), derrubou a teoria da "força vital" sintetizando, acidentalmente, a uréia a partir de cianato de prata e cloreto de amônio, desferindo poderoso golpe nos vitalistas.

A partir da metade do século XIX começam a surgir os primeiros resultados importantes sobre os trabalhos de degradação química culminando, em 1873, com a síntese da alizarina. No ano seguinte ao desta síntese, vant Hoff e Le Bel, ao mesmo tempo e isolada- mente, propõem a estrutura tetraédrica do carbono, lançando as bases fundamentais da estereoquímica.

Muito antes da proposição da geometria tetraédrica do carbono, Biot (1816) descobriu que determinadas substâncias orgânicas como o açúcar de cana, o ácido tartárico, a turpentina, etc, tanto em forma pura como em solução rodavam o plano da luz polarizada e Pasteur (1848) isolou os isômeros dextro e levo do tartarato de sódio e amônio.

Em 1916, quando G. N. Lewis propôs a ligação covalente, já se conheciam várias estruturas de substâncias orgânicas naturais, resultado de laboriosos estudos de degradação química e de síntese orgânica. Esse período representa o apogeu da síntese dos corantes.

O final dos anos vinte e toda a década de trinta pode ser caracterizado pelo grande número de trabalhos sobre o isolamento e a identificação de substâncias de natureza esteroidal. Graças principalmente aos estudos de Wieland e Windaus e colaboradores (1903-1932), o principal representante dessa classe, o colesterol, teve sua estrutura determinada. No entanto, sua síntese só foi realizada, independentemente em 1951, por Robinson e Woodward ${ }^{24}$. No ano seguinte, este último sintetizou a cortisona. A genialidade deste químico, considerado o mais expressivo do século $\mathrm{XX}$, pode ser avaliada através de suas sínteses dos alcalóides quinina (2) (1945), estriquinina (3) (1954) e reserpina (4) $(1958)^{16}$.<smiles>C=C[C@H]1CN2CC[C@H]1C[C@H]2[C@H](O)c1ccnc2ccc(OC)cc12</smiles>

2 Quinina

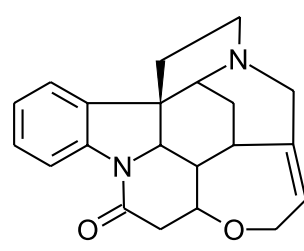

3 Estriquinina<smiles>COc1ccc2c3c([nH]c2c1)C1CC2C(C[C@H](OC(=O)c4cc(OC)c(OC)c(OC)c4)[C@H](OC)[C@H]2C(C)=O)CN1CC3</smiles>

\section{Reserpina}

Após a Segunda Guerra Mundial a disponibilidade de carbono radioativo $\left({ }^{14} \mathrm{C}\right)$ para estudos de biossíntese de Produtos Naturais imprimiu um enorme avanço neste campo. Até então, as vias biogenéticas eram de natureza especulativa. No entanto, apesar de todo empirismo, as primeiras propostas feitas por Robinson, durante as primeiras décadas do século XX, sobre as rotas de biogênese de algumas classes de alcalóides, foram comprovadas experimentalmente muitos anos depois.

Robinson, em 1929, sugeriu pela primeira vez uma provável origem biogenética da porção pirrolizidínica dos alcalóides de Senecio, propondo o aminoácido ornitina como o precursor de duas unidades C-4 que acoplariam para gerar as necinas ${ }^{25}$. Tal precursor foi comprovado por experiências que se seguiram com a incorporação do aminoácido marcado em Senecio isatideus ${ }^{26}$ e Crotolaria spectabilis ${ }^{27}$.

Entre as várias contibuições advindas do emprego de ${ }^{14} \mathrm{C}$ em investigações de biossíntese podem-se destacar a elucidação das primeiras etapas químicas da fotossíntese, a ciclização de esqualeno a triterpenos, a degradação de lanosterol a esteróis e a biossíntese de colesterol. 
A introdução dos métodos espectroscópicos e das diferentes modalidades de cromatografia na fitoquímica alterou gradualmente os objetivos e a filosofia dos trabalhos de isolamento e de determinação estrutural de Produtos Naturais.

A utilização de métodos espectroscópicos em identificação estrutural permitiu a redução das quantidades de material necessário para a análise e possibilitou, ao mesmo tempo, a determinação em curto espaço de tempo de estruturas complexas com vários centros estereogênicos.

\section{Plantas medicinais}

Plantas medicinais é um tema recorrente na pauta da ciência brasileira. Unanimidade entre químicos e farmacólogos brasileiros de reconhecida expressão internacional, os estudos com plantas medicinais ainda não receberam no Brasil, a atenção que o tema merece das agências financiadoras, embora já exista uma massa crítica de pesquisadores qualificados nas áreas de química e farmacologia. Até o presente momento, não houve um processo coordenado de todos os atores (indústria, farmacólogos, fitoquímicos, químicos sintéticos, farmacêuticos, médicos, etc) visando o desenvolvimento de fármacos a partir de plantas ${ }^{28,29}$. Na tentativa de reverter este fato, $\mathrm{o}$ $\mathrm{CNPq}$ lançou recentemente um edital de financiamento para pesquisa de validação de plantas medicinais em uso como fitoterápicos (parceria universidade-indústria).

O único recurso terapêutico de parcela da população brasileira e de mais de $2 / 3$ da população do planeta, o mercado mundial de fitoterápicos movimenta cerca de US $\$ 22$ bilhões por ano e vem seduzindo a cada ano mais adeptos nos países desenvolvidos. Em 2000, o setor faturou US\$ 6,6 bilhões nos EUA e US\$ 8,5 bilhões na Europa, sendo a Alemanha, de longe, o maior mercado mundial de fitoterápicos. O extrato padronizado de Gingko biloba é hoje um dos fitoterápicos mais vendidos no mundo e no Brasil. A balança comercial brasileira é altamente deficitária neste item. O país exporta cerca de US\$ 7 mi- lhões em extratos vegetais de alcaçuz, alóes, bardana, catuaba, ipeca e quina. Por outro lado, importa uma quantidade considerável de hormônios esteroidais, produtos cosméticos de fonte natural, verdadeiro contra-senso para uma nação que possui uma das maiores populações vegetais do planeta ${ }^{30}$. Um problema grave na comercialização de fitoterápicos no Brasil ou a possibilidade de exportação é a falta do status de medicamento ético que lhe garanta eficácia, segurança e qualidade, padrões estes mensurados em bases científicas para a segurança do usuário ${ }^{31}$. Muitos exemplos de plantas medicinais da biota brasileira poderiam ser citados, entretanto, a maioria das plantas medicinais comercializadas no Brasil são introduzidas. Assim, as plantas medicinais endêmicas ainda são pouco conhecidas e se constituem num fascinante assunto de pesquisa acadêmica e de desenvolvimento. Neste contexto, o químico de PN não só pode estar envolvido no isolamento e identificação dos constituintes ativos, como também desenvolvendo pesquisas na tentativa de validação de métodos analíticos modernos visando o controle de qualidade destas plantas.

\section{Micromoléculas de plantas}

A natureza, de forma geral, tem produzido a maioria das substâncias orgânicas conhecidas. Dentre os diversos reinos da natureza, o reino vegetal é o que tem contribuído de forma mais significativa para o fornecimento de metabólitos secundários, muitos destes de grande valor agregado devido às suas aplicações como medicamento, cosméticos, alimentos e agroquímicos ${ }^{32}$. Muitas dessas substâncias constituem-se, sobretudo, em modelos para o desenvolvimento de medicamentos sintéticos modernos, tais como procaína, cloroquina, tropicamida ${ }^{33}$, ou de fármacos imprescindíveis como, vimblastina $\left(\operatorname{Velban}^{\circledR}\right)(\mathbf{5})$, vincristina $\left(\operatorname{Oncovin}^{\circledR}\right)(\mathbf{6})$, podofilotoxina e os análogos etoposídeo (VP-16-213; Vepeside ${ }^{\circledR}$ (7) e teniposídeo $\left(\right.$ VM-26; Vumon $\left.{ }^{\circledR}\right)(8)$, taxol $\left(\right.$ Paclitaxel; Taxol $\left.{ }^{\circledR}\right)(9)$ e mais recentemente camptotecina (10) e derivados, com participação num mercado que movimenta cerca de 50 bilhões de dólares anualmente.

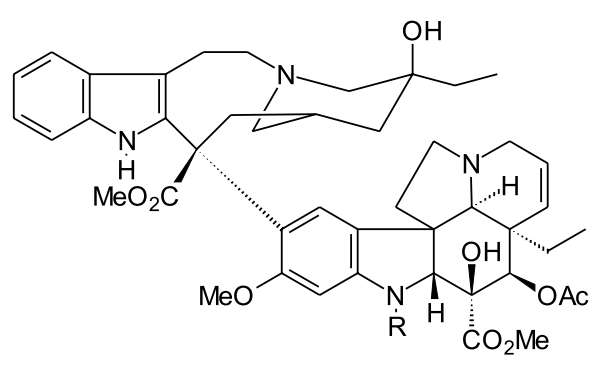

$5 \mathrm{R}=$ Me Vimblastina $6 \mathrm{R}=\mathrm{CHO}$ Vincristina

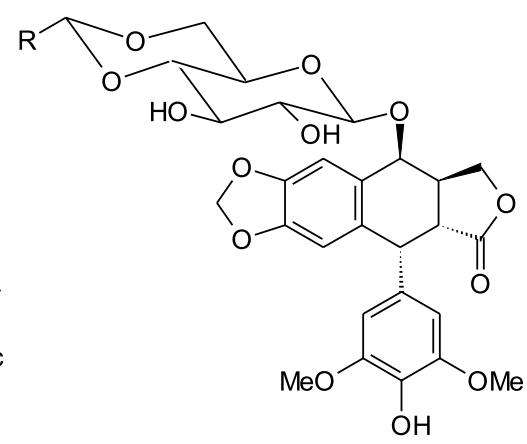

$7 \mathrm{R}=$ Me Etoposídeo

$8 \mathrm{R}={ }_{S}$ Teniposídeo<smiles></smiles>

10 Camptotecina 
Depois da descoberta destes medicamentos de origem vegetal, é possível entender a corrida entre algumas indústrias transnacionais pela busca de substâncias bioativas novas. Esta busca foi intensificada nos anos 90, especialmente nas florestas tropicais onde se concentra grande parte da biodiversidade ${ }^{34}$ e especialmente no Brasil, onde a grande maioria das espécies continua sem qualquer estudo químico ou biológico ${ }^{35}$.

Mais fantástico ainda é o acúmulo de substâncias enantiomericamente puras, pelas plantas. A preocupação da indústria farmacêutica com produtos quirais intensificou-se e o mercado de fármacos cardiovasculares, antibióticos, hormônios, vitaminas, antiinflamatórios e antitumorais enantioméricos entre 1994 e 1998 girou em torno de $27 \%$. Este mercado explodiu nos anos seguintes e o faturamento de produtos quirais produzidos a partir de espécies vegetais, só no ano passado, alcançou 45,2 bilhões de dólares. Foi muito em função desses dados que a indústria farmacêutica investiu maciçamente em programas de bioprospecção, mesmo que considere um investimento de alto risco. Nos anos noventa, o avanço das tecnologias de "highthroughput screening" (HTS) associados à química combinatória, biotecnologia e estudos genômicos mudou completamente o panorama da pesquisa em Química de Produtos Naturais praticada nos países industrializados. A fitoquímica deixou de ser o alvo. Eram necessários estudos mais abrangentes sobre a função, regulação e natureza desses produtos naturais. A biossíntese bem reconhecida de muitas classes foi o elo de transição para o entendimento de processos moleculares. A corrida vertiginosa por novos protótipos de fármacos gerou as já conhecidas "fábricas de descoberta de produtos bioativos", onde centenas de extratos poderiam ser testados em um dia.

Analisando-se o contexto nacional, o saldo contabilizado de tudo que já foi estudado não é muito animador. Se por um lado, o estudo fitoquímico de centenas de espécies vegetais revelou, no país, um time de excelência em isolamento e determinação estrutural, por outro lado não se logrou até o presente, divisas econômicas com a comercialização de um medicamento oriundo das pesquisas locais com plantas da nossa biota. Quantos lignóides, alcalóides, flavonóides, etc foram isolados? Quantos foram testados? Quantos foram acondicionados e guardados para estudos posteriores? Esses dados merecem reflexão se considerarmos que a indústria transnacional já começa a desativar programas de bioprospecção com plantas, tendo em vista a importância de medicamentos macromoleculares, devido à era pós-genômica.

A distância entre o estado da arte da Química de Produtos Naturais praticada nos países desenvolvidos e o Brasil existe mas não nos compromete. Os grupos atuais não só mudaram o enfoque básico, como também diversificaram suas pesquisas. Há grupos estudando biossíntese, ecofisiologia, ecologia, atividade biológica, entre outros.

Recentemente, uma somatória de esforços da comunidade científica, setor privado e governamental tenta reverter a distância que nos separa dos países industrializados e vários programas colaborativos foram criados (Biota-FAPESP, Bioamazônia, ExtractaBio Rio, etc). Merece destaque o programa Biota-FAPESP que nasceu da comunidade científica como uma forma de trabalho conjunto sobre a biodiversidade do Estado de São Paulo.

\section{Produtos Naturais de organismos marinhos}

Os oceanos cobrem $70 \%$ da superfície terrestre e são habitados por cerca de 200.000 espécies de plantas e invertebrados marinhos e milhões de microorganismos. Além das plantas, esponjas, octocorais, ascídeas e briozoários são organismos sésseis quando adultos e se desenvolvem em condições adversas quando comparados aos terres- tres (p. ex. maior pressão de consumo e imersos em uma "sopa" de microorganismos). A evolução e sobrevivência destas espécies resultou em organismos que produzem substâncias únicas com funções ecológicas diversas.

As pesquisas com Produtos Naturais marinhos no Brasil tiveram início na década de 60 no Centro de Pesquisas de Produtos Naturais na Faculdade de Farmácia da UFRJ ${ }^{36}$. No entanto, ainda são poucas as informações, documentadas em artigos científicos, sobre as substâncias isoladas e a atividade biológica de produtos naturais de organismos marinhos coletados ao longo dos $7500 \mathrm{~km}$ de litoral brasileiro. As poucas informações existentes sobre a química desses organismos, muitos dos quais são espécies endêmicas, indicam um grande potencial de pesquisa para a área no Brasil. Atualmente, apenas 4 grupos de pesquisa dedicam a quase totalidade de seus trabalhos ao isolamento e identificação de produtos naturais de organismos marinhos coletados no Brasil. Estes trabalhos dão ênfase à avaliação da função ecológica e/ou atividade farmacológica de substâncias isoladas de algas e invertebrados marinhos. No aspecto ecológico, os trabalhos têm sido direcionados à procura de metabólitos fagoinibidores, inibidores de crescimento de bactérias marinhas patogênicas, inibidores de bioincrustação e na descoberta de mediadores da reprodução. Quanto à atividade farmacológica, neurotoxinas e substâncias com atividade anticâncer, antiviral, anticoagulante e antitrombótica têm sido isoladas e identificadas.

A história do estudo dos Produtos Naturais marinhos demonstra que, por volta de 1960, houve um grande investimento por parte das indústrias farmacêuticas na busca de substâncias bioativas a partir dos organismos que vivem nos oceanos. Além da popularização do mergulho autônomo e do desenvolvimento de equipamentos para coleta em maiores profundidades, a descoberta de grandes quantidades de prostaglandinas em um octocoral, despertou o interesse nas pesquisas em produtos naturais marinhos. Constituindo a maior concentração de PGs na natureza (cerca de $2-3 \%$ do peso seco do octocoral Plexaura homomalla), as primeiras substâncias desta classe isoladas de organismos marinhos foram os derivados de $15 R-\mathrm{PGA}_{2}$ (11a e 11b), epímeros em C-15 das prostaglandinas de mamíferos ${ }^{37}$.

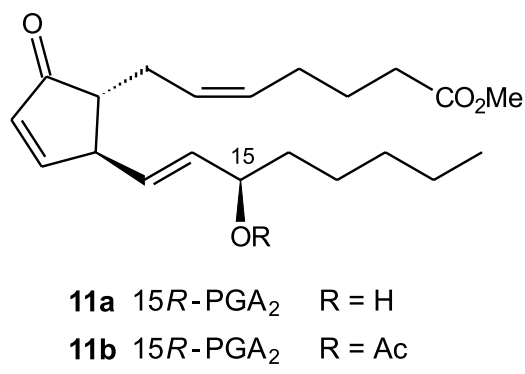

Desde então, diversos laboratórios, principalmente nos Estados Unidos, Austrália e Itália, têm se dedicado ao estudo químico de esponjas, corais, moluscos, algas, microorganismos e outros organismos marinhos. Muitas substâncias identificadas possuem estruturas químicas únicas e sem precedentes em fontes naturais terrestres; fato que tem motivado, além do desenvolvimento de novos métodos de isolamento e de síntese orgânica, pesquisas sobre a origem e biossíntese das substâncias isoladas, sua importância ecológica e atividades farmacológicas.

O estudo das substâncias químicas produzidas pelas espécies marinhas é uma ferramenta fundamental para a compreensão da evolução e da manutenção das comunidades marinhas nos diferentes oceanos ${ }^{38}$. Apesar dos estudos em ecologia química terrestre já terem sido bastante explorados, somente no início dos anos 80 é que o papel ecológico de substâncias orgânicas produzidas no ambiente 
marinho começou a ser desvendado ${ }^{39}$. Já existem várias comprovações experimentais de que pequenas moléculas orgânicas são importantes na sobrevivência das espécies estudadas. Algumas das atividades mais comumente atribuídas aos produtos naturais marinhos são as de mediação na reprodução, de defesa contra potenciais predadores, patógenos, bioincrustação ou competidores de substrato ${ }^{40}$. Somente na última década é que estas funções ecológicas começaram a ser comprovadas experimentalmente, inclusive por pesquisadores brasileiros ${ }^{41}$, revelando papéis importantes na estruturação dos ecossistemas e dando origem a outras hipóteses envolvendo o papel de metabólitos secundários afetando a biodiversidade ${ }^{38-41}$.

Acredita-se que a atividade de produtos naturais em bioensaios farmacológicos (celulares ou enzimáticos) está relacionada às propriedades de defesa do organismo produtor. Como exemplo, a briostatina (12), agente anticâncer em fase de testes clínicos, atua no briozoário Bugula neritina (do qual foi isolada) como inibidor do ciclo celular, impedindo a proliferação de organismos estranhos ${ }^{42}$.

Nos últimos 50 anos cerca de 10.000 produtos naturais marinhos foram descobertos, muitos com atividade farmacológica, incluindo acetogeninas, policetídeos, terpenos, alcalóides, peptídeos e metabólitos de origem biossintética mista ${ }^{43}$.

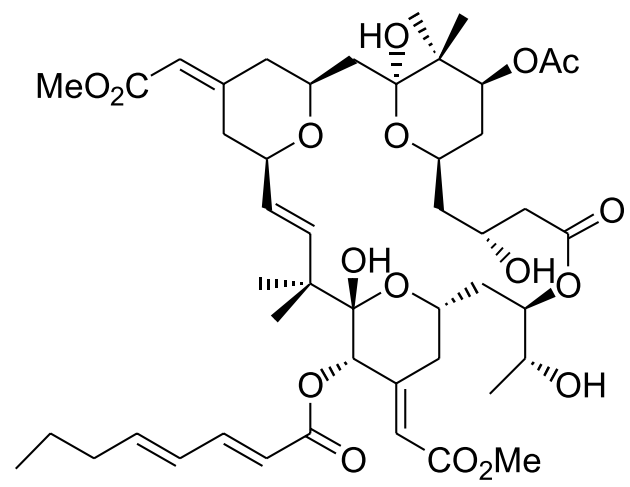

12 Briostatina

Um exemplo histórico do desenvolvimento de fármacos a partir de produtos naturais marinhos, teve origem no isolamento dos nucleosídeos espongouridina (13a) e espongotimidina (13b) por Bergmann e colaboradores nos anos 50. Isoladas da esponja Tethya crypta, estas substâncias possuem atividade antiviral e o estudo de análogos sintéticos levou ao desenvolvimento de agentes antivirais e anticâncer, tais como ARA-A (14) e ARA-C (15) ${ }^{44}$.<smiles></smiles>

13a $\quad \mathrm{R}=\mathrm{H}$<smiles>NC1=NC=NC2C1N=CN2C12OC(CO)C(O)C1O2</smiles>

14 ARA-A<smiles>Nc1ccn(C23OC(CO)C(O2)C3O)c(=O)n1</smiles>

15 ARA-C 13b $\quad \mathrm{R}=\mathrm{Me}$

No entanto, a descoberta de fármacos de origem marinha só agora alcança a maturidade com algumas substâncias já em fase clínica de testes, tais como os agentes anticâncer briostatina (12), ecteinascidina 743 (16, do tunicato Ecteinascidia turbinata) e aplidina $(\mathbf{1 7} \text {, do tunicato Aplidium albicans })^{45}$.

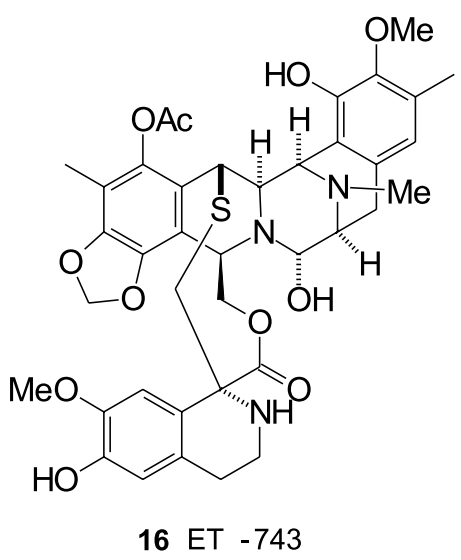<smiles>CCC(C)[C@H](NC(=O)C[C@H](C)CC(=O)[C@H](Cc1ccc(OC)cc1)N(C)C(=O)[C@@H]1CCCN1C(=O)[C@H](CC(C)C)NC(=O)[C@H](C)C(=O)[C@@H](OC(=O)C[C@@H](O)C(C)C)[C@@H](C)CC)C(=O)N[C@@H](CC(C)C)N(C)C(=O)[C@@H]1CCCN1C(=O)C(C)=O</smiles>

17 Aplidina

Algumas substâncias isoladas de ascídeas coletadas no Brasil também apresentaram atividade anticâncer significativa, tais como os depsipeptídeos tamandarinas e os alcalóides isogranulatimidas, estes últimos, inibidores seletivos e específicos do ponto de checagem do ciclo celular ${ }^{46}$.

Outros exemplos de protótipos de fármacos isolados de organismos marinhos são o esterol antiasmático contignasterol (18) e o diterpeno antiinflamatório pseudopterosina A $(\mathbf{1 9})^{45}$. As pseudopterosinas já são comercializadas como substâncias ativas de uma linha de cremes faciais, denominada Resilience, da Estée Lauder. Como resultado das pesquisas com o contignasterol e com as pseudopterosinas, desenvolveram-se os derivados semi-sintéticos denominados IPL576,092 e methopterosina, respectivamente. O primeiro já se encontra em fase II de testes clínicos, enquanto que o segundo foi aprovado recentemente pela FDA (Food and Drug Administration, EUA) para dar início à fase $\mathrm{I}^{47,48}$.

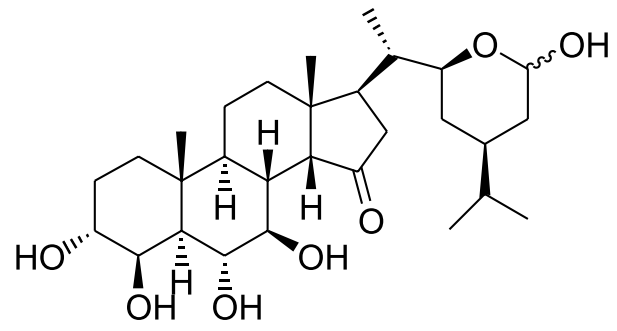


<smiles></smiles>

19 Pseudopterosina A

Os estudos sobre polissacarídeos sulfatados com atividades anticoagulante e antitrombótica, isolados de algas, ascídeas, pepinos e ouriços-do-mar, são os mais significativos na área de produtos naturais marinhos no Brasil. Como exemplo do resultado dessas pesquisas, o sulfato fucosilado de chondroitina, isolado do pepino-domar Ludwigothurea grisea apresenta-se como alternativa promissora para a heparina, por suas atividades anticoagulante e antitrombótica $^{49}$.

A dificuldade de cultivo de macroorganismos marinhos ou de síntese de moléculas complexas em grande escala têm dificultado o desenvolvimento de fármacos de origem marinha. Por outro lado, várias substâncias com atividade farmacológica são suspeitas de serem produzidas por microorganismos associados, passíveis de cultura em larga escala. Isso explica, pelo menos em parte, o interesse crescente no estudo de microorganismos marinhos isolados de sedimentos, da água do mar, de macroalgas, peixes e invertebrados ${ }^{40,43}$. Recentemente, pesquisadores da Universidade da Califórnia identificaram a bactéria, endossimbionte do briozoário Bugula neritina, responsável pela produção da briostatina (12). A bactéria Candidatus Endogobula sertula é um simbionte verdadeiro e as tentativas de cultivo têm sido em vão. Por outro lado, a identificação e seqüenciamento do gene responsável pela síntese do anticâncer 12, abre novas perspectivas para a produção industrial do fármaco. A clonagem do gene e sua expressão em bactérias heterólogas hospedeiras pode ser o caminho na produção em larga escala de briostatinas e análogos, assim como de outros produtos naturais com estruturas complexas ${ }^{50}$.

\section{Produtos Naturais de microorganismos}

Os produtos farmacêuticos juntamente com os agroquímicos são hoje considerados os dois pilares de sustentação da civilização moderna. A frase mens sana in corpore sano é, certamente, o produto ideal de um projeto científico interdisciplinar, cujo resultado final é a qualidade de vida da espécie humana. Neste contexto, os produtos naturais isolados de microorganismos, de uma forma geral, têm uma importância sem precedentes não só como medicamentos (exemplo antibióticos), mas, principalmente como agroquímicos menos danosos à saúde humana.

Os países desenvolvidos consomem cerca de 60 a $70 \%$ de produtos herbicidas na proteção de suas agriculturas. Só nos EUA, o merca- do de herbicidas está estimado em cerca de 4 bilhões de dólares anuais ${ }^{51}$. Este dado, aliado ao fato de uma tomada de consciência das políticas públicas locais, sobre os malefícios dos herbicidas poluentes (derivados clorados e fosfatados), colocam a pesquisa com microorganismos na agenda da pesquisa de PN brasileira. Recentemente, pesquisa neste tema vem sendo explorada por diversos grupos de Produtos Naturais espalhados no país. O uso de sistemas enzimáticos in vivo para reações de biotransformação são objeto de estudos já há alguns anos nos laboratórios da UNICAMP, UFMG, UFPR, UFSCar e mais recentemente no IQ-USP. Microorganismo associado (fungos e bactérias endofíticos) é também outro tema recorrente da pesquisa em QPN realizada hoje no Brasil. Estes microorganismos vivem em associação íntima com plantas hospedeiras vivas e sadias e acreditase, atualmente, que muitas substâncias bioativas que ocorrem em plantas podem ser produzidas por microorganismo associado. No estado de São Paulo, a UFSCar deu o passo inicial pesquisando fungos associados em plantas de Rutaceae e Meliaceae. Recentemente, o IQ-UNESP também começa a se dedicar a este estudo focalizando principalmente plantas de Cerrado e Mata Atlântica.

Uma das propriedades mais importantes dos microorganismos, em especial dos fungos, está associada à sua capacidade metabólica de produzir uma grande diversidade de micromoléculas bioativas. Não obstante, os fungos são responsáveis também pela produção de substâncias altamente tóxicas para mamíferos, conhecidas como micotoxinas, algumas consideradas carcinogênicas potentes. Entre as micotoxinas incluem-se aflatoxinas (20), ocratoxinas (21), citreoviridinas (22), tricotecenos e fumonisinas, além de uma variedade de derivados indólicos tremorgênicos ${ }^{52}$. Acredita-se que as toxinas produzidas por fungos sejam menos tóxicas que as substâncias produzidas por bactérias, plantas e outras fontes.

Nos ambientes tropicais, os fungos constituem-se num sério problema no processo de armazenamento de alimentos, principalmente de cereais, devido à produção de micotoxinas tóxicas que contaminam alimentos e passam a ser um sério problema de saúde pública.

Por outro lado, fármacos importantes de uso clínico em várias patologias foram obtidos de fungos ${ }^{53}$. Esta dicotomia de funções pode ser proveniente da grande diversidade química que os fungos produzem. Em 1994, dos vinte medicamentos mais vendidos, representando um mercado de aproximadamente 6,7 bilhões de dólares, seis deles $^{54}$, foram obtidos in natura ou por transformação química de metabólitos provenientes de fungos. Dentre os medicamentos de maior repercussão terapêutica para doenças infecciosas destacam-se os antibióticos penicilinas (23) e cefalosporinas (24) como os exemplos mais conhecidos de produtos de fungos. Recentemente, muitas substâncias com outras atividades farmacológicas foram produzidas a partir de metabólitos de fungos. Um exemplo notável é a mevinolina (25) (mevacor = lovastatina), um agente redutor de colesterol, detentor de um mercado mundial em torno de U\$1 bilhão por ano. Outras substâncias de grande relevância como medicamento incluem ciclosporinas (26) e alcalóides ergot (27). Numerosos metabólitos de fungos vêm sendo descobertos como fármacos potenciais, incluindo asperlicina (antagonista de doenças gastrointestinais e SNC) (28), papulacandinas (29) (antifúngico), entre outros ${ }^{53,55}$.<smiles>COc1cc2c(c3oc(=O)c4c(c13)CCC4=O)[C@H]1CCO[C@@H]1O2</smiles>

20 Aflatoxina $B 1$<smiles>CCOCCOCCOC</smiles><smiles>COC(=O)OC1C(=O)C2=CCOC3=C2C1(C)c1ccc2c(c1C3=O)CCC2=O</smiles> 


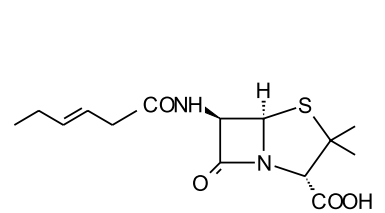

23 Penicilina F<smiles>[R4][C@H](C)O[C@H](N)[C@H](N)OC=O</smiles><smiles>CC(CO)NC(=O)C1C=C2c3cccc4[nH]cc(c34)C[C@H](C)[C@H]2CN1</smiles>

27 Ergometrina $\dot{H}$<smiles>CCC(C)C(=O)OC1CC(C)C=C2C=CC(O)C(CCC3CC(O)CC(=O)O3)C2C1</smiles>

25 Mevinolina

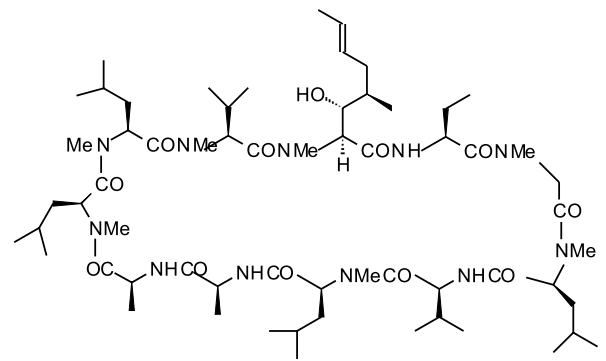

26 Ciclosporina A

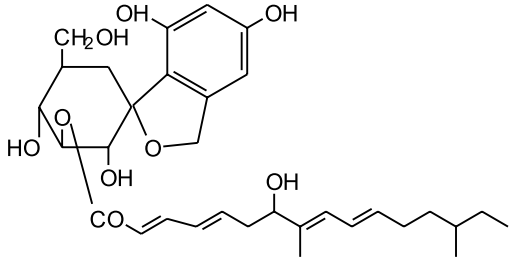

29 Papulacandina
As substâncias isoladas de fungos destacam-se também como agroquímicos naturais ${ }^{56}$, tais como destruxinas (inseticidas) e estrobilurinas (fungicidas), além de várias fitotoxinas (herbicidas).

Com relação à ocorrência e biodiversidade, os fungos constituem-se no segundo maior grupo de espécies sobre a terra, perdendo apenas para os insetos. Estimativas sugerem que há aproximadamente 1,5 milhões de espécies diferentes de fungos, sendo que menos de $5 \%$ foram descritas ${ }^{57}$.

Assim, constata-se nos últimos anos uma prioridade de pesquisa sobre a química dos fungos, temendo-se a perda da biodiversidade ${ }^{58}$. Muitas espécies ameaçadas de plantas superiores e insetos estão associadas com a flora específica dos fungos e, se estas perdas ocorrerem, poderão resultar no desaparecimento das espécies de fungos.

A busca de princípios bioativos de microorganismos é uma das áreas em que mais se investe nos países desenvolvidos, principalmente nas pesquisas de bioprospecção realizadas pelas indústrias farmacêuticas ${ }^{59}$.

A utilização de produtos obtidos de fungos no controle biológico da agricultura vem crescendo de maneira marcante ${ }^{60}$. Destacamse nesse processo a utilização de certos fungos como micoerbicidas, micoinseticidas ou micoparasitas.

Devido à produção de grande quantidade e diversidade de metabólitos secundários, os fungos competitivos são considerados uma fonte valiosa de produtos com atividade farmacológica.

Entre os fungos oportunistas, os pesquisadores especialistas na área vêm dando um destaque especial aos aquáticos, ainda pouco estudados, mas, também, uma fonte inesgotável de substâncias bioativas. Estes fungos, como microorganismos competitivos, acumulam uma grande diversidade de micromoléculas, muitas dessas com atividade biológica de interesse ${ }^{61}$.

\section{Química de Produtos Naturais e a proteção de plantas}

Em 1976, sob os auspícios da Academia Pontifícia de Ciências do Vaticano, realizou-se na cidade do Vaticano, a semana de estudos "Produtos Naturais e a Proteção de Plantas". As discussões travadas nessa reunião focalizaram o papel de determinados metabólitos secundários na defesa de plantas contra organismos predadores. A importância deste tema pode ser avaliada pela destruição cada vez maior dos cultivares de cereais pelo ataque de pragas, que chega a causar a perda de $1 / 3$ da produção mundial de cereais. Este problema vem sendo agravado pela prática cada vez mais freqüente de monoculturas e pela resistência dos predadores aos inseticidas sintéticos.

A busca por inseticidas naturais ganhou enorme impulso depois da descoberta dos efeitos indesejáveis aos ecossistemas dos inseticidas sintéticos, que tem no DDT seu principal vilão.

Plantas possuem suas próprias defesas que as protegem de outras plantas, insetos fitófagos e herbívoros predadores de uma maneira geral. Estas defesas são de natureza química e, normalmente, envolvem substâncias do metabolismo secundário, as quais podem ser chamadas de fitotoxinas ou aleloquímicos. Esse fenômeno é conhecido como alelopatia. A primeira interação planta-planta foi descrita pelo naturalista romano Plínio, que observou que sob a copa das nogueiras não crescem outros vegetais. Hoje se sabe que a fitotoxina responsável por este fenômeno é a juglona (30), um poderoso inibidor de germinação, presente na forma de glicosídeo nas folhas, que sofre hidrólise e oxidação à quinona no solo.

A definição mais recente de alelopatia, aquela que é aceita pela Sociedade Internacional de Alelopatia, é muito abrangente, como pode ser vista a seguir: "É a ciência que estuda qualquer processo envolvendo, principalmente, metabólitos secundários produzidos por plantas, algas, bactérias e fungos que influenciam o crescimento de sistemas biológicos com efeitos positivos e negativos". Uma definição tão ampla como esta para alelopatia dificulta até se afirmar o que sejam aleloquímicos. Estes vão dos fagorrepelentes às fitoalexinas, para citar apenas dois casos de alelopatia.

Fagorrepelentes, do inglês "antifeedants", são substâncias naturais que têm a propriedade de interromper o pastejo, podendo o efeito ser temporário ou permanente. Os fagorrepelentes geralmente agem sobre o sistema nervoso central dos insetos e são específicos para determinadas espécies. Um exemplo clássico de fagorrepelente é a azadiraquitina (31), um triterpeno isolado de Azadirachta indica e 
Melia azedarach, muito ativo sobre Schistocerca gregaria, o gafanhoto do deserto. Outros fagorrepelentes muito potentes contra a chamada lagarta dos cereais, Leucania spp, são os sesquiterpenos poligodial e ugandensial, isolados de espécies da família Canellaceae.<smiles>O=C1C=CC(=O)c2c(O)cccc21</smiles>

30 Juglona

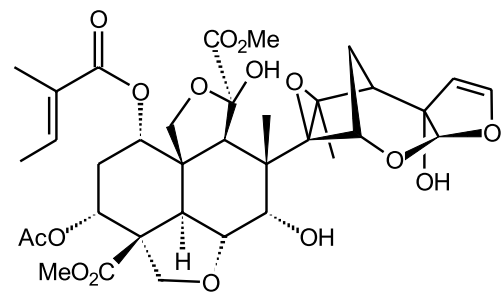

31 Azadiraquitina
As fitoalexinas são substâncias com propriedades antimicrobianas produzidas pelas plantas quando estas são infectadas por microorganismos fitopatogênicos como vírus, bactérias e fungos, ou quando as plantas estão sob condições de estresse, como secura, frio, ação de luz ultravioleta, etc. As fitoalexinas aparecem, geralmente, em altas concentrações em resposta à infecção, desempenhando nas plantas um papel semelhante ao dos anticorpos nos animais.

Apesar das fitoalexinas incluírem várias classes de produtos naturais, existe uma relação entre a natureza química destas substâncias de defesa com famílias botânicas. Por exemplo, as leguminosas geralmente produzem isoflavonóides, as solanáceas, diterpenos, asteráceas, poliacetilenos e as orquidáceas, diidrofenantrenos.

As fitoalexinas poderão ter no futuro um papel muito importante na agricultura. Na medida que sejam conhecidos os mecanismos de ação dos eliciadores (substâncias que ativam o processo de defesa) nos hospedeiros e de como as plantas biossintetizam estes compostos, poder-se-á chegar à imunização de plantas de valor econômico contra doenças causadas por fitopatógenos.

Os vegetais desenvolvem mecanismos de defesa contra patógenos (vírus, bactérias, fungos, insetos, etc) produzindo toxinas contra o agente invasor e adquirindo resistência à infecção. Desde a década de 60, esses mecanismos são conhecidos mas, somente nos últimos anos, os patologistas vegetais vêm-se dedicando ao estudo das bases moleculares e genéticas deste fenômeno.

Recentemente foi descoberto o envolvimento do ácido salicílico (AS) e de seu derivado acetilado (AAS) nas reações de defesa contra patógenos. O ácido salicílico é acumulado no tecido vegetal após a infecção, provocando uma resposta imune, chamada de resistência sistêmica adquirida (SAR).

O ácido salicílico foi descrito como a molécula sinalizadora no desenvolvimento da SAR no fumo e no pepino. No fumo, o nível de AS aumentou em mais de 40 vezes nas imediações da lesão por onde penetrou o patógeno.

A SAR, pelo que se sabe, está relacionada à ação de genes que comandam a proteção de proteínas, as quais atuam como antibióti$\cos$ nos animais. Experimentos em que foram aplicados ácido salicílico em folhas de fumo (Nicotiana tabacum) levaram a uma reação do tipo SAR, como se o patógeno (neste exemplo, o vírus do mosaico do tabaco) estivesse presente. Por outro lado, observou-se que quando a formação de ácido salicílico foi bloqueada, a atividade SAR desapareceu ou diminuiu, enfraquecendo a resistência do vegetal. Algumas substâncias sintéticas análogas ao AS também induzem a SAR , como o ácido 2,6-dicloro isonicotínico, o qual induz a mesma classe de genes da SAR, produzindo o mesmo espectro de resistência observado pela indução biológica.

O AS parece que também desempenha papel importante na morte celular programada provocada pela infecção causada por patógenos.
Os altos níveis de AS acumulados no tecido infectado podem ser suficientes para inibir uma catalase, levando ao aumento da concentração de $\mathrm{H}_{2} \mathrm{O}_{2}$ nos locais da infecção. A morte celular no local infectado oferece vantagens para a planta, visto que a morte da célula hospedeira interrompe o fluxo de nutrientes para o patógeno invasor impedindo sua multiplicação para outras células. No caso do patógeno ser um vírus, este só sobrevive se hospedando em células vivas. No arroz (Oryza sativa), por exemplo, o ácido salicílico é biossintetizado a partir do ácido cinâmico.

Outra substância de estrutura química muito simples e importante no sistema de defesa de plantas e que vem sendo alvo de estudos, por parte dos bioquímicos vegetais, é o jasmonato de metila (32). Esta substância é indutora da produção de inibidores de enzimas que decompõem proteínas (proteinases), de proteínas antifúngicas e de enzimas envolvidas na biossíntese de metabólitos secundários de defesa (Esquema 1). Desta forma, além das funções já bem conhecidas no desenvolvimento e na regulação do crescimento vegetal, os jasmonatos têm papel importante como fitoormônios ou transdutores na sinalização de defesa de plantas.

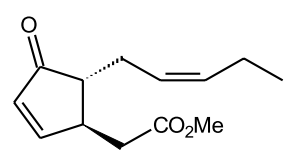

32 Jasmonato de metila

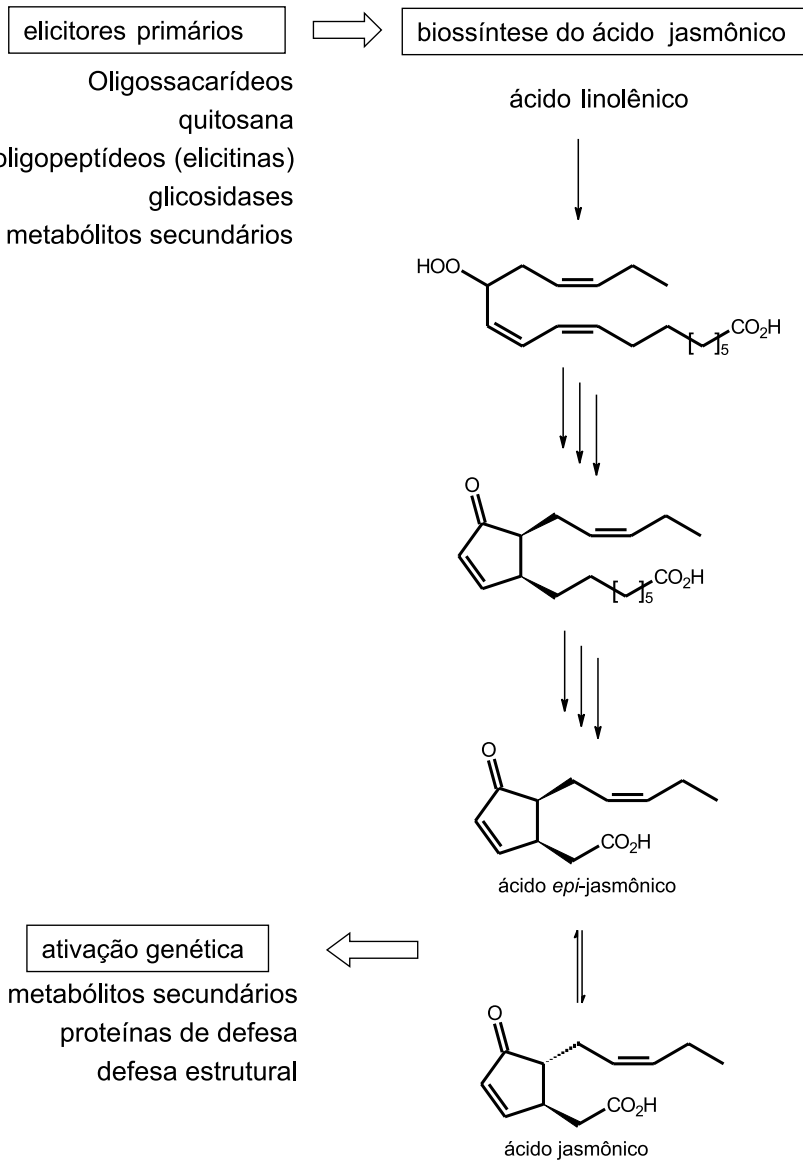

Esquema 1. Elicitação da produção e ação do ácido jasmônico ${ }^{62}$ 
Pesquisas recentes mostram que determinadas plantas desenvolveram um sofisticado sistema de defesa para proteção contra herbívoros predadores. Um dos exemplos mais fascinantes é a estratégia de defesa do milho, Zea mays, contra a lagarta Spodoptera exigua. $\mathrm{O}$ milho quando é atacado por este predador emite uma mistura de substâncias voláteis constituída de indol, mono e sesquiterpenos, que atrai fêmeas da vespa parasita Cotesia marginiventris, um predador natural da lagarta. Estas substâncias são liberadas quando a secreção oral do herbívoro entra em contato com o tecido ferido da planta. Feridas mecânicas não provocam a emissão das substâncias de defesa. Além disso, a liberação desses voláteis só ocorre no período do dia quando as vespas parasitas estão em busca de alimento do seu hospedeiro. A planta responde ao ataque do patógeno produzindo jasmonatos, que induzirão genes a codificar enzimas que estão envolvidas na biossíntese dos metabólitos secundários do sistema defensivo da planta (Esquema 2) ${ }^{62}$.

Outro exemplo que mostra a beleza do processo adaptativo planta-planta e de como os químicos de Produtos Naturais com suas pesquisas podem trazer grandes benefícios para a humanidade relaciona-se com a erva daninha Striga asiatica, uma das mais devastadoras pragas das culturas cerealíferas no mundo. Esta planta parasita diminui as reservas alimentares de quase meio milhão de pessoas na Ásia e na África. Striga asiatica possui um verdadeiro radar químico e só germina, podendo permanecer latente no solo por muito tempo, quando a planta hospedeiro libera estrigol (33). No momento da liberação, a parasita agarra-se às raízes do hospedeiro e dela se alimenta.

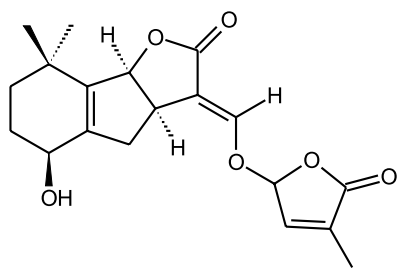

33 Estrigol

Graças às pesquisas dos químicos de Produtos Naturais que desvendaram os mecanismos de interação parasita-hospedeiro e que determinaram as estruturas químicas dos metabólitos secundários que estão envolvidos nessa interação, os agricultores antes de se- mearem os cereais lançam no solo estrigol ou seus derivados sintéticos que induzem a germinação das sementes da erva parasita. $\mathrm{O}$ ciclo de crescimento de Striga asiatica é de 4 dias, que morrerá, após germinar, sem nunca ter encontrado seu hospedeiro, deixando o solo livre para a plantação ${ }^{63}$.

\section{Programas atuais de bioprospecção nos países industrializados}

Apesar da grande importância da bioprospecção em países em desenvolvimento e com grande potencial em termos de biodiversidade, as novas realidades legislativas e comerciais levaram a um novo enfoque na busca de produtos naturais bioativos por parte das grandes companhias farmacêuticas. Este fato pode ser constatado pela desativação dos centros de bioprospecção como o da Abbott Pharmaceuthical e da Pfizer $^{64}$. Atualmente, os grandes grupos multinacionais farmacêuticos têm discutido a aplicação das tecnologias baseadas na genômica, onde o enfoque passa a ser macromolecular (peptídeos, proteínas, etc) ao invés de micromolecular (substâncias naturais ou sintéticas) ${ }^{65}$. O grande estímulo para esta mudança são os valores agregados a medicamentos ligados a doenças de origem genética como Alzheimer, câncer, artrite entre outros. Por outro lado, doenças tropicais ou de fundo inflamatório, entre outras, requerem ainda micromoléculas. Contudo o alto custo das tecnologias de "highthroughput screening" (HTS) levou à seleção de uma quantidade muito pequena de fármacos em relação às milhares de matrizes complexas (extratos vegetais ou de organismos marinhos) testadas, o que claramente não interessa às grandes multinacionais ${ }^{66}$.

Quando nos deparamos com estas informações somos levados a pensar, em um primeiro momento, que a indústria perdeu a credibilidade nos produtos de origem natural. Esta não é uma informação correta. O momento atual para os grandes capitais é a tentativa de estar na vanguarda tecnológica, com isso obtendo novos mercados. Mas mesmo com o fluxo contrário, ainda é clara a possibilidade de descoberta de novos protótipos a partir de substâncias naturais e para algumas empresas, maior que em qualquer processo sintético. Por essas razões, atualmente os grandes grupos farmacêuticos estão investindo na tecnologia de "highthroughput screening" de substâncias puras, o que representa uma considerável economia. Em 1998, a Rhône-Poulenc Röhrer (hoje parte da Aventis) decidiu estrategicamente abandonar os ensaios com extratos brutos e iniciou os ensaios de substâncias puras na busca de atividade biológica. Esta

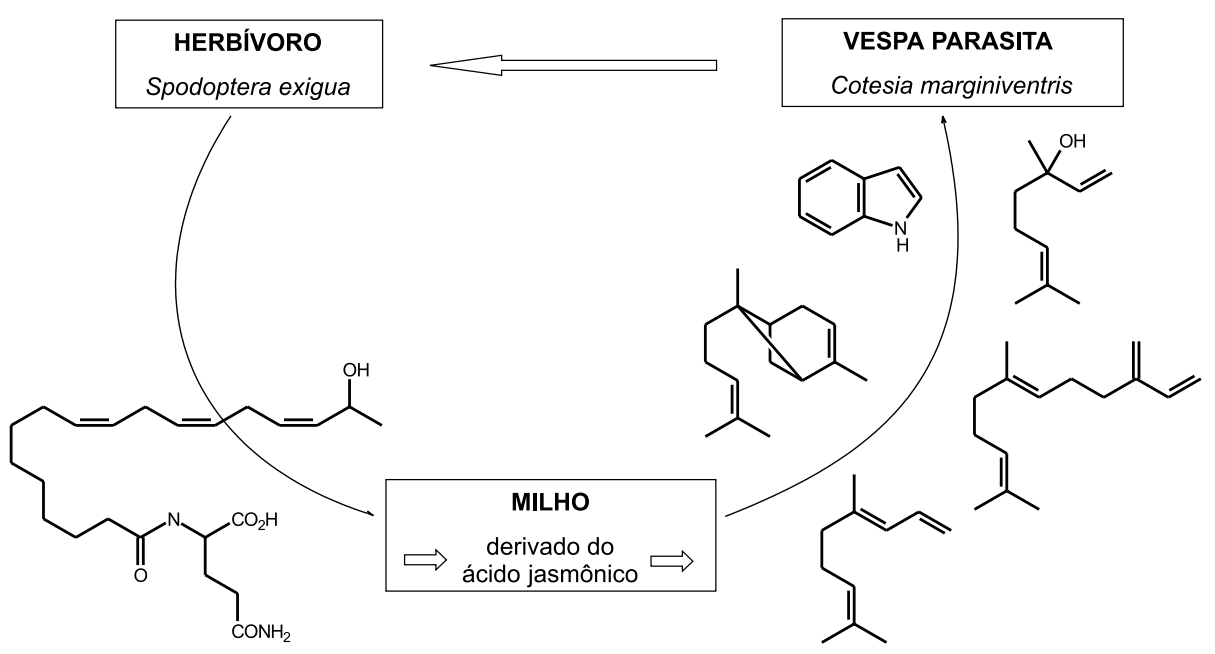

Esquema 2. Sistema de defesa química do milho (Zea mays) sob ataque da lagarta Spodoptera exígua $^{62}$ 
decisão resultou em marcante redução de custos e de tempo na obtenção de um protótipo. Neste enfoque, a indústria necessitou de 18 meses para o isolamento de 4000 produtos naturais das mais diversas classes e fontes na faixa de $5 \mathrm{mg}$ e com pureza em torno de $80 \%$. Estas substâncias são utilizadas para os testes de "highthroughput screening". Outras empresas não só se preocupam com a criação de bibliotecas de substâncias, como também criam bancos de dados para a comparação de matrizes por CLAE-EM, como o caso da AnalytiCom Discovery ${ }^{66}$.

Considerando que no período de 1983 a 1994 foram aprovados 529 novos fármacos e dentre estes, $39 \%$ são produtos naturais ou derivados semi-sintéticos, e a vasta biodiversidade brasileira, ainda pouquíssima estudada, fica clara a necessidade de estudos de bioprospecção. Outro dado relevante é a capacidade tecnológica instalada no Brasil e o grande número de grupos especialistas na área com competência para que, num futuro próximo, possam criar uma grande biblioteca de substâncias puras para ensaios de "highthroughput screening" (HTS) ${ }^{67}$.

\section{Técnicas hifenadas dentro do novo contexto das pesquisas com Produtos Naturais}

Atualmente, a possibilidade do emprego de técnicas hifenadas ou técnicas acopladas pode ajudar, em parte, os estudos em Produtos Naturais. Apesar de extratos vegetais serem misturas complexas de diferentes metabólitos, a análise de frações voláteis ou materiais apolares de superfícies foliares já é, há muito tempo realizada, não sendo necessário muitas vezes, nenhum fracionamento para a total caracterização química do material em estudo. O grande avanço na análise destas misturas decorreu do desenvolvimento de aparelhos de cromatografia gasosa acoplada à espectrometria de massas (CGEM), os quais são empregados rotineiramente, por exemplo, na indústria de essências. Conforme citado acima, a grande limitação desta técnica é a possibilidade de analisarmos apenas substâncias que podem ser volatilizadas e, em muitos casos, o emprego do impacto eletrônico na geração dos íons limita também o uso para substâncias instáveis ${ }^{68}$.

O emprego das primeiras técnicas acopladas à cromatografia líquida de alta eficiência (CLAE) abriu a possibilidade do uso de outros sistemas de detecção, como ultravioleta (UV), infravermelho (IV), eletroquímico e fluorescência, entre outros. Nenhum destes sistemas novamente pode ser considerado universal, mas possibilita a análise de matrizes não voláteis e de alto peso molecular. Apesar da limitação da existência de cromóforos na molécula para o detector de UV, o desenvolvimento do arranjo de diodos (DAD - "diode array detector") estimulou o seu emprego em PN. Uma rápida consulta no "Web of Science" mostra como esta técnica foi e tem sido muito empregada por exemplo no controle de qualidade de plantas medicinais, busca de metabólitos ativos, em estudos de ecologia química e até estudos quimiossistemáticos, como a análise de tricomas glandulares. Além da vantagem de obtermos o espectro de UV de cada substância, o que fornece uma informação estrutural, o baixo preço do equipamento em relação a outras técnicas foi a principal alavanca para seu sucesso. Contudo, a necessidade de uma maior informação estrutural de cada componente das matrizes analisadas levou ao desenvolvimento de técnicas hifenadas mais modernas, como o acoplamento da CLAE com EM e com ressonância magnética nuclear (RMN).

O maior desenvolvimento e emprego das técnicas de ionização de MALDI (ionização por dessorção a laser com auxílio de matriz) e ESI (ionização por "electrospray") no início dos anos 90 possibilitou a análise de moléculas termolábeis, complexos organo-metálicos e moléculas de elevada massa molecular incluindo polímeros e proteínas $^{69}$. Estes feitos ajudaram a popularizar a técnica nas mais diferentes áreas das ciências biológicas, desde a análise de praguicidas no solo $^{70}$ até a identificação e caracterização de danos oxidativos ao DNA $^{71}$, passando pela Química de Produtos Naturais ${ }^{72}$. Quase a totalidade dos analisadores de massas requerem os íons na fase gasosa e Vestal ${ }^{73}$ mostra, em recente revisão, o grande número de equipamentos utilizando técnicas diversas de geração de íons existentes hoje no mercado.

No Brasil, a maioria dos instrumentos de CLAE-EM possui o ESI como fonte geradora de íons. Por se tratar de ionização branda (assim como outras técnicas correlatas), no espectro de EM são observados apenas os íons quasi moleculares $[\mathrm{M}+\mathrm{H}]^{+} \mathrm{e}[\mathrm{M}+\mathrm{Na}]^{+}$. Este fato é extremamente importante para a determinação da massa molecular de um analito e facilita os estudos quantitativos em CLAEEM. Para obtermos a fragmentação deste composto é necessário o acoplamento de dois analisadores de massas com uma célula de colisão entre eles (EM/EM). No primeiro analisador ocorre a seleção do íon de interesse. Este íon é então introduzido na célula de colisão onde colide com um gás inerte (argônio, nitrogênio, etc) levando à sua fragmentação. Finalmente, os fragmentos obtidos são analisados no segundo instrumento acoplado ${ }^{68}$. O número de diferentes analisadores de massas disponíveis no mercado também aumenta, contudo, as pesquisas envolvem principalmente o acoplamento entre eles (EM/EM). O quadrupolo-quadrupolo e suas variações, o quadrupolo/tempo de vôo (Q-ToF) e o quadrupolo-ressonância ciclotrônica de íons com transformada de Fourier (FT-ICR) são alguns exemplos de analisadores acoplados empregados no estudo de Produtos Naturais. A definição da biossíntese do antibiótico tetronasina e seus derivados é um exemplo de aplicação recente da técnica de $\mathrm{ESI}-\mathrm{EM} / \mathrm{EM}^{74,75}$. A análise da eritromicina A por ESI-FTICR possibilitou a definição dos passos de fragmentação do anel ${ }^{76} \mathrm{e}$, posteriormente à análise de seus análogos, foi possível localizar a posição onde ocorre a primeira perda de água, utilizando moléculas marcadas com ${ }^{18} \mathrm{O}^{77}$. O antibiótico monensina A e seu derivado também tiveram suas vias de fragmentação elucidadas devido à alta resolução apresentada nas análises de FT-ICR. Apesar dos espectros de $\mathrm{EM} / \mathrm{EM}$ dos íons $[\mathrm{M}+\mathrm{H}]^{+}$e $[\mathrm{M}+\mathrm{Na}]^{+}$apresentarem fragmentos com a mesma massa em baixa resolução, foi demonstrado em estudos de alta resolução tratar-se de estruturas completamente diferentes $^{78}$.

A CLAE-EM é atualmente o método mais sensível de análise e o melhor para o emprego em quantificação ${ }^{79}$. Com as informações anteriores torna-se evidente a possibilidade da determinação de novos derivados naturais em CLAE-EM/EM. Contudo, a técnica mais poderosa para determinação estrutural de substâncias inéditas com novos esqueletos e, principalmente, em misturas biologicamente ativas é a CLAE-RMN. Recentes progressos em gradientes de pulso de campo, supressão de solventes, a possibilidade de altos campos magnéticos (400-800 MHz), entre outros, têm re-estimulado o uso desta técnica que teve seu início no final da década de 70, mas que, sem as atuais vantagens não alcançou grandes avanços. A maior limitação do uso do equipamento é a baixa concentração do analito e o alto custo dos solventes. Normalmente utilizamos misturas de solventes para separação em CLAE, e com exceção do óxido de deutério $\left(\mathrm{D}_{2} \mathrm{O}\right)$, todos os outros solventes deuterados são muito caros. Atualmente as novas técnicas de supressão têm possibilitado o uso de solventes não deuterados (metanol e acetonitrila), mas também podem comprometer a análise de determinadas regiões do espectro. Aparelhos de 750 a $800 \mathrm{MHZ}$ aliados a novas técnicas de aquisição de dados têm solucionado os problemas de sensibilidade, contudo os problemas com os dados de ${ }^{13} \mathrm{C}$ ainda não foram totalmente superados. Dependendo da concentração do analito e da sua estrutura, a aquisição de dados pode ser em fluxo contínuo ou com interrupção do fluxo. Esta segunda possibilidade tem auxiliado na obtenção de espectros de boa 
qualidade. Em sua recente revisão sobre o assunto, Wolfender ${ }^{79}$ relata o emprego da técnica com bons resultados para um grande número de classes de metabólitos secundários aromáticos, para lactonas sesquiterpênicas, esteróides, saponinas e iridóides de várias espécies com atividade biológica.

Apesar da clara utilidade da CLAE-RMN, até o presente momento, desconhecemos a existência deste equipamento em qualquer grupo de pesquisa em Produtos Naturais no Brasil. A maior limitação é o seu altíssimo preço além do alto custo da manutenção. Por outro lado, o grande número de técnicas de ionização introduzidas em CLAE-EM/EM, o aumento da resolução dos analisadores e a comparação dos custos com CLAE-RMN mostram um futuro muito promissor para o emprego desta técnica nos próximos anos pela comunidade de PN.

\section{Perspectiva da Química de Produtos Naturais dentro da era genômica}

O homem sempre procurou entender a natureza da vida e as chances de alcançá-la e, pelo menos em nível molecular, nunca esteve tão próximo. Novas informações sobre genes e suas funções, em parte, são responsáveis por uma revolução tecnológica dirigida para as ciências da vida. Cabe neste momento ao químico brasileiro, parar e refletir sobre o que nós realmente precisamos saber para passarmos da compilação de dados para o entendimento destes. Neste texto, vamos comentar e mostrar que o momento é propício para se iniciar a modelagem do perfil metabólico de plantas da nossa biota, principalmente daquelas de interesse econômico como fármacos e/ ou agroquímicos. Este novo evento vai emergir da necessidade de se colocar a química de Produtos Naturais realizada no Brasil dentro dos novos paradigmas da pesquisa internacional, cujo enfoque nesta e nas próximas décadas, estará centrado na genômica funcional de plantas. À frente na ciência brasileira, a Biologia Molecular já inclui entre suas grandes realizações o seqüenciamento genético de microorganismos patógenos como Xylella fastidiosa responsável pela CVC (Clorose Variegada de Citrus) e o genoma da cana de açúcar, que deve levar a variedades mais produtivas e resistentes. Essas conquistas representam um marco na ciência brasileira, possível graças à ação coordenada de pesquisadores em torno de um objetivo comum e o financiamento expressivo da FAPESP ${ }^{80}$.

O modelo clássico da genética foi uma ferramenta valiosa para a biologia e os avanços da era pós-genômica. Ela revelou dados valiosos sobre a essência molecular em diversos processos, como a divisão celular, morte programada da célula e desenvolvimento embrionário. Estes eventos, hoje bem documentados, foram consequiência dos estudos com Saccharomyces cerevisiae, Caenorhabditis elegans e Drosophila melanogaster ${ }^{81,82}$. Foram muitos anos de pesquisa para se chegar ao estágio da compreensão genômica. As próximas etapas vão tratar das reações do panorama metabolômico.

Genômica, termo que nos últimos dois anos ocupou todos os meios de comunicação, é a atividade de seqüenciar genomas e derivar informações teóricas a partir da análise do conjunto da expressão genética de um indivíduo, utilizando ferramentas computacionais, enquanto genômica funcional define o status do transcriptoma e do proteoma de uma célula, tecido ou organismo sob condições definidas; em outras palavras, determina a função dos genes num organismo. O objetivo final da pesquisa proteômica vai além da simples catalogação de proteínas que uma célula expressa em seu estado normal ou doente. O objetivo maior é a elucidação da rede regulatória e sinalizadora da organização e da dinâmica metabólica pelo qual a vida de uma célula é processada.

Além disso, a proteômica busca o entendimento de como estas redes (malha metabólica) tornam-se disfuncionais nas células anor- mais (doentes). Assim, ao se dominar as funções celulares, pode-se manipulá-las para geração de células sadias ou ainda produção de fármacos planejados de acordo com cada evento genético disfuncional. Esta é a meta mais ambiciosa e nobre da pesquisa em biologia molecular, em especial da fase proteômica atual, e requer tecnologia de alta sensibilidade e conceitos novos, além daqueles já dominados nas áreas genética e química.

O conhecimento metabólico e de diagnose da célula já estão muito avançados com relação a microrganismos ${ }^{83}$. Na fase atual, a pesquisa está voltada para o "mapa celular" ou proteoma estrutural ${ }^{84,85}$, cujo objetivo imediato é identificar a estrutura das proteínas e, em particular, identificar quais interagem com as formas complexas de outras proteínas no evento metabólico celular. Para este fim as ferramentas tecnológicas disponíveis, altamente sofisticadas têm sido 2DE (eletroforese bidimensional) e EM e o avanço neste campo não tem precedentes, pois hoje se trabalha com a 2DE/EM hifenados, como 2DEPAGE e MALDI-ToF/EM ${ }^{86}$.

A genômica de plantas ainda não atingiu o status das genômicas de microrganismos e animais, entretanto, com o seqüenciamento do genoma de Arabidopsis thaliana, primeira espécie vegetal a ter seu código genético completamente decifrado, tem início uma nova fase na pesquisa sobre biologia molecular de plantas e principalmente sobre o conhecimento de genes de regulação metabólica ${ }^{87}$. A possibilidade de se utilizar genes regulatórios e suas associações com compartimentalização (de extrema importância na regulação das vias metabólicas secundárias) foi demonstrada pela ativação e produção de antocianinas em células de Arabidopsis e de milho, que se processam por ativação dos transcriptomas $\mathrm{R}$ e $\mathrm{C}^{88,89}$. Recentemente, trabalho sobre a biossíntese de alcalóides indólicos em Catharanthus roseus resultou no isolamento de genes regulatórios ${ }^{90}$. Mesmo com essas evidências, até o presente, a maior parte das vias metabólicas de plantas continua sem qualquer conhecimento sobre a função dos genes regulatórios. Outro dado relevante para a compreensão da relação gene/metabolismo secundário está na variação da concentração e diversificação desses metabólitos, que possivelmente estão relacionados com uma determinada função enzimática. Isto sugere que a função do gene pode ser decifrada comparando-se os perfis da variação da concentração dos metabólitos.

A. thaliana teve seu genoma completamente decifrado ${ }^{87}$. A questão que se abre no momento é o que se fazer com a quantidade de informação armazenada; o ceticismo de que todo o conhecimento genético produzido sobre esta erva poderá ser benéfico para a agricultura. Artigo recente sobre esta polêmica mostrou engenhosamente que $A$. thaliana pode ser uma planta modelo para desenvolvimento agrícola, e quem sabe, no futuro ser uma planta comestível.

Numa dada espécie vegetal, a soma total dos efeitos de todos os genes representa o fenótipo desta planta e a única maneira de definir o fenótipo em um momento qualquer da vida desta planta (organismo) é defini-la no nível de moléculas. Se por um lado as macromoléculas representam a estrutura do organismo, as micromoléculas são mais especializadas e estão envolvidas nos processos metabólicos das células. São elas que participam da interação das células e do organismo com o meio ambiente, ou seja, são substâncias sinalizadoras, envolvidas na defesa contra pragas e doenças e na atração e polinização, eventos cruciais para a manutenção de determinada espécie sobre a terra.

A análise qualitativa e quantitativa dos eventos moleculares primários e secundários é a etapa final da genômica funcional e a este conjunto completo de informações de uma determinada célula chamamos de metaboloma. No estágio atual, quase toda atenção está centrada no proteoma, muito embora ainda não seja possível analisar-se todas as proteínas. Ainda, estudos recentes revelam que não há muita lógica na interação entre proteína e metabólito secundário, 
como há entre os genes e as proteínas ${ }^{90}$. A única relação entre macro e micromoléculas que pode ser diagnosticada com o conhecimento atual, é que antes do metabólito ser formado, os genes envolvidos na sua produção precisam ser transcritos e traduzidos por uma proteína codificada. Em alguns casos, esta relação pode ser estabelecida sem o conhecimento prévio do proteoma. Em outras palavras, a combinação de metaboloma com transcriptoma pode, em muitos casos, ser suficiente para estabelecer a genética das vias metabólicas. É importante salientar também que, para plantas, além da caracterização das micromoléculas e das proteínas, existem outras macromoléculas tipo celulose e lignina, que deveriam ser analisadas dentro do enfoque genômico. O perfil metabólico (metaboloma) não é apenas de interesse para a genômica funcional, mas também para várias outras situações importantes, sendo uma delas, a aplicação desse conhecimento na produção de transgênicos seguros à saúde humana.

Somente o mapeamento e a comparação de todas as substâncias produzidas por uma determinada espécie selvagem e seu organismo transgênico poderão apontar os riscos ou não das plantas obtidas por engenharia molecular. Outro interesse para a aplicação dos avanços da biologia molecular é para os agricultores, devido à possibilidade de se determinar as propriedades ou características de cada parte específica da planta (resistência contra pragas e doenças, sabor, cor etc) Finalmente, o conhecimento do perfil metabólico será fundamental também para o controle de qualidade de fitofármacos. Somente a identificação de produtos bioativos de interesse em matrizes complexas de plantas, através de "screenings" rápidos, permitirá a descoberta de novos fármacos em tempo recorde.

Resumindo, o arsenal químico micromolecular tem mostrado uma importância econômica indiscutível, principalmente pela vinculação à química fina, para produção de fragrâncias, tintas, alimentos, fármacos, inseticidas, corantes, antioxidantes, cosméticos, etc. A possibilidade de modificação genética das plantas que produzem tais produtos abre uma excitante perspectiva de pesquisa sobre a biossíntese desses metabólitos e sobre o mecanismo de formação dessas vias metabólicas em nível celular.

A química de Produtos Naturais na era pós-genômica continua sendo uma ferramenta fundamental para o entendimento dos mecanismos metabólicos de cada parte da célula e das funções desses metabólitos em determinada unidade celular ${ }^{90}$, mesmo sabendo-se que nenhuma dessas substâncias está envolvida nos processos metabólicos básicos da célula, mas que respondem pela sinalização, adaptação, polinização e defesa. O mais complexo e fascinante no estudo prospectivo de plantas é que cada táxon possui um sistema próprio, caracterizado por metabólitos específicos: alcalóides, terpenóides, fenólicos, etc. Dentro dessa premissa, cerca de 100.000 substâncias de plantas são conhecidas e estima-se que cerca de 4.000 novas são descritas a cada ano $^{91}$.

A natureza vegetal será sempre uma fonte inesgotável de substâncias úteis, como os metabólitos secundários, mas quase sempre produzidos em quantidades insuficientes para qualquer utilidade econômica. Diante deste fato, os mecanismos celulares de regulação e produção destas substâncias poderão ser modificados para que sejam produzidas in natura, por interferência nos genes responsáveis pela regulação metabólica de uma espécie de interesse, ou serem produzidas por cultura celular programada.

\section{CONCLUSÕES E PERSPECTIVAS}

A espécie humana se aproveita de uma fração muito pequena das plantas com as quais sempre conviveu e que a antecedem no planeta Terra. O reino vegetal ainda permanece como uma grande incógnita cujos mistérios começam a serem desvendados.

A humanidade, ao longo do tempo selecionou apenas cerca de
300 plantas para a alimentação e, de um pouco mais de uma centena, obteve princípios ativos puros para o tratamento de doenças. Estes números são bem modestos quando se está diante de um universo de aproximadamente 250.000 espécies de plantas superiores.

Segundo estimativas recentes feitas por dois pesquisadores americanos, as florestas tropicais úmidas guardam apenas 328 drogas úteis à medicina. Se esta previsão for levada em consideração pela indústria farmacêutica, pode-se supor que as gigantes desse mercado não investirão na bioprospecção das florestas, porque o retorno financeiro é muito reduzido diante do volume de recursos necessários que devem ser investidos para um empreendimento dessa magnitude. A literatura científica está repleta de previsões como esta, cujo interesse maior parece ser definir valores econômicos para hectares de florestas de importância vital para a sobrevivência e bem estar das populações das nações desenvolvidas. Se for necessária a internacionalização de certas áreas de floresta, o preço da terra já foi calculado em bases científicas. Previsões à parte, uma verdade sobressai. Não pode existir vida na terra sem a presença das plantas e, estudá-las, sob qualquer que seja a ótica científica, é parte do domínio da química de Produtos Naturais.

Em futuro próximo, a humanidade terá ao seu dispor as biofábricas vegetais, onde cultivares de mamão ou bananas geneticamente modificadas, por exemplo, substituirão as fábricas de vacinas, no que será conhecido como setor agrocêutico. Arroz e soja transgênicos, além de resistentes a pragas, serão vitaminados. Os primeiros passos nessa direção foram dados com a decifração do código do mapa genético do arroz, a base da dieta de mais da metade da população mundial.

Pode-se antecipar que solos contaminados com metais pesados e com material radioativo, hoje impossíveis de serem ocupados, serão descontaminados com plantas, no que já é chamado de fitoremediação, e que plantas substituirão os combustíveis fósseis como fontes renováveis de energia limpa.

Os químicos de PN serão atores importantes no palco do futuro. O domínio das plantas vai ser possível quando o mundo mágico das enzimas for melhor compreendido e as vias metabólicas totalmente conhecidas. Expressar ou silenciar genes será atividade rotineira na biologia molecular, quando biólogos e químicos, em pareceria, perscrutarem o fundo das células vegetais vivas, seus núcleos, cromossomos e genes $^{92}$. Já se começou a caminhada nessa direção e a participação dos químicos de Produtos Naturais será cada vez mais importante para que esse caminho seja percorrido mais depressa. $\mathrm{O}$ domínio das técnicas analíticas e preparativas de separação, tanto de metabólitos secundários como de macromoléculas de plantas, como das técnicas de identificação dessas mesmas moléculas, é parte da rotina da química de Produtos Naturais nos países industrializados. Isso não significa que a comunidade brasileira de química de Produtos Naturais abandone seus projetos de bioprospecção de fármacos novos para se engajar nos mega-projetos de decifração de códigos genéticos ou deixe de procurar nas plantas a razão de sua resistência a pragas. Mas, também é imperativo que os grupos novos de fitoquímicos não se limitem a continuar fazendo o que aprenderam com seus mestres para deixarem de ser clones científicos.

A história da QPN brasileira dos próximos 25 anos certamente terá outros narradores, que num exercício de futurologia traçarão outros cenários. Até lá pode-se esperar que a ciência retome seu caminho natural para melhor compreensão dos sistemas vivos e deixe de ser o grande balcão de negócios no qual vem se transformando, fator de hegemonia cada vez maior das nações ricas. Seja qual for o cenário futuro é necessária a preservação das florestas e os químicos de Produtos Naturais têm obrigação de defendê-las para as próximas gerações, nem que seja para perpetuar a cultura de presentear o próximo com uma bela orquídea. 


\section{AGRADECIMENTOS}

Os autores agradecem gentilmente ao Dr. I. Castro-Gamboa, bolsista de pós-doutorado FAPESP, IQ-UNESP, Araraquara, pela valiosa colaboração na preparação desse manuscrito e ao Professor R. Verpoorte, Leiden University, Holanda, pelo envio de separatas sobre biologia molecular e discussão valiosa sobre genômica de plantas.

\section{REFERÊNCIAS}

1. Veiga Jr., V. F.; Pinto, A. C.; Quim. Nova, 2002, 25, 273.

2. Pinto, A. C.; Quim. Nova, $1995,18,608$.

3. Carneiro, E.; A Conquista da Amazônia, Coleção Mauá, Ministério da Viação e Obras Públicas, Serviço de Documentação: Rio de Janeiro, 1956.

4. Freedberg, D.; Ciência, Comércio e Arte em o Brasil dos Holandeses 16301654, Herkenhoff, P., org.; GMT Editores Ltda.: Rio de Janeiro, 1999.

5. Costa, A. M. M.; Bol. Soc. Port. Quim. 1986, 23, 37.

6. dos Santos, N. P.; Pinto, A. C.; de Alencastro, R. B.; Quim. Nova 1998, $21,666$.

7. Halpen, O.; Schmid, H.; Helv. Chim. Acta, 1958, 41, 123.

8. Carrara Jr., E.; Meirelles, H.; A Indústria Química e o Desenvolvimento do Brasil - 1560-1889, Metalivros: São Paulo, 1996.

9. Mors, W. B.; Ciência e Cultura 1997, 49, 310.

10. Motidome, M.; Lecking, M. E.; Gottlieb, O. R.; An. Acad. Bras. Ci. 1970, 42 (Supl), 375.

11. Valle, J. R.; A Farmacologia no Brasil, Antecedentes e Perspectivas, Academia de Ciências do Estado de São Paulo: São Paulo, 1978.

12. Siqueira, M. D.; Curso de Química: 60 Anos de História, Curitiba: Universidade Federal do Paraná, 1999.

13. Rheinboldt, H. Em As Ciências no Brasil; Azevedo, F. de, ed.; Melhoramentos: São Paulo, 1955, vol. 2, cap. VIII.

14. de Faria, L. R.; História, Ciência, Saúde-Manguinhos 1997, 4, 51.

15. Mathias, S.; Cem Anos de Química no Brasil, Coleção da Revista de História, São Paulo,1975, LXIII.

16. http://www.sbq.org.br/PN-NET/ e http://www.cnpq.gov.br, acessada em Março 2002.

17. http://www.biota.org.br, acessada em Março 2002.

18. Myers, N.; Mittermeier, R. A.; Mittermeier, C. G.; Da Fonseca, G. A. B.; Kent, J.; Nature 2000, 403, 853.

19. Vilela, J. D.; Rev. Paul. Med. 1977, 89, 115.

20. Mahran, G.; Medicina Tradicional 1977, 1, 23.

21. Anderson, R. G. W.; Chem. Br. 1983, 19, 822.

22. Mors, W. B.; Ciência Hoje 1982, 1, 14.

23. Marini-Bettòlo, G. B.; Ciência e. Cultura 1974, 26, 751.

24. Woodward, R. B.; Sondheimer, F.; Taub, D.; Heusler, K.; McLamore, W. M.; J. Am. Chem. Soc. 1951, 73, 2403; ibid 3547; ibid 1952, 74, 4223; Cardwell, N. M. E.; Cornforth, J. W.; Duff, S. R.; Holtermann, H.; Robinson, R.; Chem. Ind. 1951, 389; J. Chem. Soc. 1953, 361.

25. Robinson, R.; The Structural Relations of Natural Products, Clarendon Press: Oxford, 1975.

26. Nowacki, E.; Byerrum, R. U.; Life Sci. 1962, 5, 157.

27. Hughes, C. A.; Letcher, R.; Warren, F. L.; J. Chem. Soc. 1974, 4979.

28. Brito, A R.; Brito, A. A .S.; J. Ethnopharmacol. 1993, 39, 53.

29. Ferreira, S. H.; Barata, L. E. S.; Salles, S. L. M.; Queiróz, S. R. R.; Heluy Neto, N. E.; An. Acad. Bras. Ci. 1998, 12, 33.

30. Fernandes, L. R.; Antunes, A. S.; Informações Estratégicas sobre Plantas Medicinais Obtidas a partir de Bases de Dados em Linha Mimeo, Escola de Química, Universidade Federal do Rio de Janeiro: Rio de Janeiro, 2000.

31. Siani, A. C., Gilbert, B.; Riopharma 2000, 18.

32. Phillipson, G. W.; Anderson, A. C.; J. Ethnopharmacol. 1998, 25, 61.

33. Kinghorn, D.; O’Neil, M. O.; ACS Symp. Ser. 1996, $179,647$.

34. Rouhi, A. M.; Chem. Eng. News 1997, 7, 214

35. Cordell, G. W; ACS Symp. Ser. 1995, 588, 8.

36. Kelecom, A.; Ciência e Cultura 1997, 49, 321.

37. Weinheimer, A. J.; Spraggins, R. L.; Tetrahedron Lett. 1969, 59, 5185; Valmsen, K.; Järving, I.; Boeglin, W. E.; Varvas, K.; Koljak; R.; Pehk, T.; Brash, A. R.; Samel, N.; P. Natl. Acad. Sci. U.S.A. 2001, 98, 7700; Schneider, C.; Boeglin, W. E.; Prusakiewicz, J. J.; Rowlinson, S. W.; Marnett, L. J.; Samel, N.; Brash, A. R.; J. Biol. Chem. 2002, 277, 478.

38. Hay, M. E.; Fenical, W.; Oceanography 1997, 9, 10.

39. Paul, V. J., ed.; Em Ecological Role of Marine Natural Products; Publishing Associates: Comstock, 1992; Pawlik, J. R.; Chem. Rev. 1993, 93, 1911; Hay, M. E.; J. Exp. Mar. Biol. Ecol. 1996, 200, 103; Millar, J. G.; Haynes, K. F., eds.; Em Methods in Chemical Ecology: Biological Method; Kluwer Academic Publishers: London, 1998.
40. McClintock, J. B.; Baker, B. J., eds.; Em Marine Chemical Ecology; CRC Press: New York, 2001.

41. Maia, L. F.; Epifanio, R. de A.; Eve, T.; Fenical, W.; J. Nat. Prod. 1999, 62, 1322; Epifanio, R. de A.; Maia, L. F.; Fenical, W.; J. Braz. Chem. Soc. 2000, 11, 584; Epifanio, R. de A.; Martins, D. L.; Villaça, R.; Gabriel, R.; J. Chem. Ecol. 1999, 25, 2255; Epifanio, R. de A.; Gabriel, R.; Martins, D. L.; Muricy, G.; J. Chem. Ecol. 1999, 25, 2247; Teixeira, V. L.; Cavalcanti, D. N.; Pereira, R. C.; Biochem. System. Ecol. 2001, 29, 313; Pereira, R. C.; Cavalcanti, D. N.; Teixeira, V. L.; Mar. Ecol. Prog. Ser. 2000, 205,95 .

42. Hung, D. T.; Jamison, T. F.; Schrieber, S. L.; Chem. Biol. 1996, 3, 623.

43. Faulkner, D. J.; Nat. Prod. Rep. 2002, 19, 1.

44. Newman, D. J.; Cragg, G. M.; Snader, K. M.; Nat. Prod. Rep. 2000, 17, 215; Pettit, G. R.; Lippert, J. W.; Taylor, S. R.; Tan, R.; Willians, M. D.; J. Nat. Prod. 2001, 64, 883.

45. Wright, E. M. Em Biodiversity: New Leads for the Pharmaceutical and Agrochemical Industries; Wrigley, S. K.; Hayes, M. A.; Thomas, R.; Chrystal, E. J. T.; Nicholson, N., eds.; Royal Society of Chemistry: Cambridge, UK, 2000, p. 113-139.

46. Veervot, H.; Fenical, W.; Epifanio, R. de A.; J. Org. Chem. 2000, 65, 782; Berlinck, R. G. S.; Britton, R.; Piers, E.; Lim, L.; Roberge, M.; Rocha, R. M.; Andersen, R. J.; J. Org. Chem. 1998, 63, 9850; Roberge, M.; Berlinck, R. G. S.; Xu, L.; Anderson, H.; Lim, L. Y.; Curman, D.; Stringer, C. M.; Friend, S. H.; Davies, P., Vincent, I.; Haggarty, S. J.; Kelly, M. T.; Britton, R.; Piers, E.; Andersen, R. J.; Cancer Res. 1998, 58, 5701.

47. Look, A. S.; Fenical, W.; Jacobs, R. S.; Clardy, J.; Proc. Natl. Acad. Sci. U.S.A. 1986, 83, 6238; Roussis, V.; Wu, Z.; Fenical, W.; J. Org. Chem. 1990, 55,4916

48. http://www.ag.auburn.edu/biotech/seagrant.htm e http:// www.inflazyme.com/products_technology.shtml, acessadas em Fevereiro 2002.

49. Pavão, M. S.; An. Acad. Bras. Ci. 2002, 74, 105.

50. Haygood, M. G.; Davidson, S. K.; Appl. Env. Microbiol. 1997, 63, 4612; Davidson, S. K.; Allen, S. W.; Lim, G. E.; Anderson, C. M.; Haygood, M. G.; Appl. Env. Microbiol. 2001, 67, 4531.

51. Ainsworth, S.; J. Chem. Eng. News 1996, 74, 35

52. Miller, J. D.; Trenholm, H. L., eds.; Em Mycotoxins in Grain: Compounds other than Aflatoxin; Eagan Press: Minnesota, 1994, p. 552.

53. Masurekar, P. S. Em Biotechnology of Filamentous Fungi: Technology and Products; Finkelstein, D. B.; Ball, C., eds.; Butterworth-Heinemann: Boston, 1992, p. 241.

54. Czarnik, A. W.; Acc. Chem. Res. 1996, 29, 112.

55. Caporale, L.H.; Proc. Natl. Acad. Sci. U.S.A. 1995, 92, 75.

56. Gardner, W. A.; McCoy, C. W.; ref. 53, p. 335.

57. Hawksworth, D. L.; Mycol. Res. 1991, 95, 641.

58. Balandrin, M. F.; Kinghorn, A. D.; Farnsworth, N. R. Em Human Medicinal Agents from Plants; Balandrin, M. F.; Kinghorn, A. D., eds.; American Chemical Society: Washington D.C. 1993, p. 2.

59. Dreyfus, M. M.; Chapela, I. H. Em The Discovery of Natural Products with Therapeutic Potential; Gullo, V. P., ed.; Butterworth-Heinemann: Boston, 1994, p. 49.

60. Powell, K. A. Em Exploitation of Microorganisms; Jones, D. G., ed; Chapman and Hall: London, 1993, p. 441.

61. Shearer, C. A.; Zare-Maivan, H.; Mycologia 1988, 80, 31.

62. Schröder, F.; Angew. Chem., Int. Ed. 1998, 37, 1213.

63. Chang, M.; Netzly, D. H.; Butler, L. G.; Lyan, D. G.; J. Am. Chem. Soc. 1986, 108, 7858.

64. Khosla, A.; Chemtracts. Org. Chem. 1998, 11, 1.

65. Bindseil, K.; Jakupovic, J.; Wolf, D.; Drug Discovery Technol. 2001, 6 , 16.

66. Houghton, P. J.; Phytother. Res. 2001, 14, 419.

67. Kato, M. J.; Phytochemistry 2001, 57, 621.

68. Crews, P.; Rodrígues, J.; Jaspar, M.; Organic Structure Analysis, Oxford University Press: New York, 1998, p. 552.

69. Smith, R. D.; Loo, J. A.; Loo, R. O.; Busman, M.; Udseth, H. R.; Mass Spectrom. Rev. 1991, 10, 359

70. Baglio, D.; Kotizias, D.; Larsen, B. R.; J. Chromatogr., A 1999, 854, 207.

71. Liao, P. C.; Li, C. M.; Hung, C. W.; Chen, S. H.; J. Mass Spectrom. 2001, $36,336$.

72. Wolfender, J.-L.; Rodrígues, S.; Hostettmann, K.; J. Chromatogr. 1998, 794, 299.

73. Vestal, M. L.; Chem. Rev. 2001, 101, 361.

74. Less, S. L.; Handa, S.; Leadlay, P. F.; Dutton, C. J.; Staunton, J.; Tetrahedron Lett. 1996, 37, 3511.

75. ibid ref. 74, 3515 .

76. Gates, P. J.; Kearney, G. C.; Jones, R.; Leadlay, P. F.; Staunton, J.; Rapid Commun. Mass Spectrom. 1999, 13, 242. 
77. ibid ref. 76,1650 .

78. Lopes, N. P.; Stark, C. B. W.; Hong, H.; Gates, P. J; Stauton, J.; Rapid Commun. Mass Spectrom. 2002, 16, 414.

79. Wolfender, J.-L.; Rodrígues, S.; Hostettmann, K.; J. Chromatogr. 1998, 794, 299.

80. Simpson, A. J. G.; Reinach, F. C.; Arruda, P.; et al.; Nature 2000, 406, 151

81. Hartwell, L. H.; Genetics 1991, 4, 975.

82. Nusselein-Volhard, C.; Wieschaus, E.; Nature 1980, 287, 795.

83. Van Bogelen, R. A.; Schiller, E. E.; Thomas, Z. D.; Weidhardt, F. C.; Electrophoresis 1999, 20, 2149.

84. Blackstock, W. P.; Weir, M. P.; Trends Biotechnol. 1999, 17, 121.

85. Anderson, M. L.; Matheson, A. D.; Steiner, S.; Curr. Opin. Biotechnol. 2000, 11, 408 .
86. Gygi, S. P.; Rist, B.; Aubersold, R.; Curr. Opin. Biotechnol. 2000, 11, 396.

87. Meincke, D. W.; Cherry, J. M.; Dean, C.; Rounsley, S. D.; Koornneef, M.; Science 1998, 282, 662.

88. Geotewold, E.; Chanberlin, M.; Snook, M.; Siame, B.; Butler, E.; Swenson, J.; Maddock.; Plant Cell. 1998, 10, 721.

89. Martin, C.; Curr. Biol. 1996, 7, 130.

90. Verpoorte, R.; van der Heijden, R.; ten Hoopen, H. J.G.; Memelink, J.; Biotechnol. Lett. 1999, 21, 467.

91. Jacobs, D. I.; van der Heijden, R.; Verpoorte, R.; Phytochem. Anal. 2000, 11, 277.

92. Enriquez, J.; Nature 1998, 281, 925.

\section{APÊNDICE}

Número de filiados: 316 (atual)

\author{
2000-2002 \\ DIRETOR: \\ VICE-DIRETOR: \\ TESOUREIRO:
}

Frederico Guaré Cruz

Massuo Jorge Kato

Norberto Peporine Lopes

Vanderlan da Silva Bolzani

Edilberto Rocha Silveira

Norberto Peporine Lopes

Paulo Cezar Vieira

Nídia Franca Roque

João Batista Fernandes

Nídia Franca Roque

Raimundo Braz Filho

Paulo Cezar Vieira

\section{Nídia F. Roque}

Juceni Pereira Chaves

Paulo Roberto Ribeiro Costa
DIRETOR:

VICE-DIRETOR:

TESOUREIRO: 